IZA DP No. 5702

The Impact of Minimum Wages on Wages, Work and Poverty in Nicaragua

Enrique Alaniz

T. H. Gindling

Katherine Terrell

May 2011 


\title{
The Impact of Minimum Wages on Wages, Work and Poverty in Nicaragua
}

\author{
Enrique Alaniz \\ FIDEG, Nicaragua \\ T. H. Gindling \\ University of Maryland Baltimore County \\ and IZA \\ Katherine Terrell \\ University of Michigan, \\ CEPR and IZA
}
Discussion Paper No. 5702
May 2011

IZA

P.O. Box 7240

53072 Bonn

Germany

Phone: +49-228-3894-0

Fax: +49-228-3894-180

E-mail: iza@iza.org

\begin{abstract}
Any opinions expressed here are those of the author(s) and not those of IZA. Research published in this series may include views on policy, but the institute itself takes no institutional policy positions.

The Institute for the Study of Labor (IZA) in Bonn is a local and virtual international research center and a place of communication between science, politics and business. IZA is an independent nonprofit organization supported by Deutsche Post Foundation. The center is associated with the University of Bonn and offers a stimulating research environment through its international network, workshops and conferences, data service, project support, research visits and doctoral program. IZA engages in (i) original and internationally competitive research in all fields of labor economics, (ii) development of policy concepts, and (iii) dissemination of research results and concepts to the interested public.
\end{abstract}

IZA Discussion Papers often represent preliminary work and are circulated to encourage discussion. Citation of such a paper should account for its provisional character. A revised version may be available directly from the author. 


\section{ABSTRACT \\ The Impact of Minimum Wages on Wages, Work and Poverty in Nicaragua*}

We use an individual-level panel data set to study the impact of changes in legal minimum wages on a host of labor market outcomes in Nicaragua including: a) wages and employment, b) transitions of workers across jobs (in the covered and uncovered sectors) and employment status (unemployment and out of the labor force), and c) transitions into and out of poverty. We find that changes in the legal minimum wage affect only those workers whose initial wage (before the change in minimum wages) is close to the minimum. For example, increases in the legal minimum wage lead to significant increases in the wages and decreases in employment of private covered sector workers who have wages within $20 \%$ of the minimum wage before the change, but have no significant impact on wages in other parts of the distribution. The estimates from the employment transition equations suggest that the decrease in covered private sector employment is due to a combination of layoffs and reductions in hiring. Most workers who lose their jobs in the covered private sector as a result of higher legal minimum wages leave the labor force or go into unpaid family work; a smaller proportion find work in the public sector. Our analysis of the relationship between the minimum wage and household income finds: a) increases in legal minimum wages increase the probability that a poor worker's family will move out of poverty, and b) increases in legal minimum wages are more likely to reduce the incidence of poverty if they impact the head of the household rather than the non-head.

JEL Classification: J3, O17

Keywords: minimum wages, employment, poverty

Corresponding author:

T. H. Gindling

Department of Economics

University of Maryland Baltimore County

Baltimore, Maryland 21250

USA

E-mail: gindling@umbc.edu

\footnotetext{
* Accepted for publication in Labour Economics. This paper was written as part of a larger project funded by the Canadian International Development Research Center (IDRC) research grant number 104242-001, administered by the Fundación Salvadoreña para el Desarrollo Económico y Social (FUSADES). We are grateful to the IDRC for funding and to Markus Frölich, Albert Berry, Alvaro Trigueros, Margarita Beneke, Alejandro Martínez Cuenca, Edgard Rodriguez and Wendy Takacs for helpful suggestions.

Katherine Terrell passed away unexpectedly on December 29th 2009. Without her enthusiasm and guidance this paper would never have been written. Her contributions to the understanding of labor markets in developing countries have been extensive and will be missed.
} 


\section{Introduction}

The justification for minimum wage legislation is to redistribute income to low wage workers. This policy tool can be especially important in developing countries during periods of rapid adjustment to the global economy. However, in an era when global competition is very strong, some policy makers argue for reductions in (and even the abolition of) minimum wages and other labor market regulation in developing countries to allow for more labor market flexibility and increased competitiveness (see e.g., Heckman and Pages, 2000). The main argument is that rigidities in the labor market, such as wage rigidity caused by the minimum wage, can slow down job creation and in turn contribute to unemployment and poverty (see e.g., Pagés and Micco, 2006). On the other hand, fierce competition in the globalized world created an environment that some have termed "the race to the bottom." There is concern that wages and working conditions are driven down by global competition and there is a need to uphold the bottom with regulations such as the minimum wage and labor standards. In fact, Acemoglu (2001) argues that minimum wages can shift the composition of employment toward high-wage jobs. If so, increases in minimum wages could contribute to the reduction of poverty and inequality by increasing the incomes of those affected by the legislation and perhaps even creating new higher wage jobs.

In this paper, we examine the impact of minimum wages on several outcomes in the labor market. First, we investigate the extent to which minimum wages raise wages and/or lower employment in the sector covered by minimum wage legislation. Second, we also study the dynamics in the labor market following increases in minimum wages. Do workers forced out of employment in the covered sector become unemployed or move into employment in the uncovered sector? Does employment in the covered sector fall because employers reduce new hires or because they lay off workers? To answer these questions, we examine the employment transitions of workers from the private covered to private uncovered sectors and the public sector, and employment transitions across employment status (from employment to unemployment and out of the labor force). The size of these flows will indicate the magnitude of the impact of the minimum wage and the extent to which workers become better or worse off. Finally, we examine the impact 
of minimum wage legislation on household income and ask if it is an effective policy tool for poverty reduction.

Nicaragua provides an excellent location to study minimum wages because the country has: (a) a relatively high level of legal minimum wages compared to average wages, which means that minimum wages have the potential to affect a large fraction of the population; (b) substantial variation in minimum wages both across industries and over time; (c) a large proportion of private sector workers not legally covered by minimum wages (the self-employed); and (d) a large sector of small firms where employers often avoid minimum wage legislation.

The study of the impact of minimum wages in developing economies has been a fruitful area of research in recent years. Recent papers include studies of Brazil, Chile, Colombia, Costa Rica, Honduras, Indonesia, Kenya, Trinidad and Tobago, Turkey and South Africa. ${ }^{1}$ In these papers, researchers have studied the impact of minimum wages on: average wages and the distribution of wages; employment, unemployment and hours worked; the distribution of wages and employment between the formal and informal sectors; and poverty. ${ }^{2}$ In our paper, we extend this literature in several ways. First, we estimate the impact of minimum wages on wages and employment in Nicaragua, a country not previously studied. Second, we estimate the impact of minimum wages separately on new hires vs. layoffs. Ours is the first study of a developing economy to explicitly show that minimum wages not only result in workers leaving the covered

\footnotetext{
${ }^{1}$ These studies include: Brazil (Lemos, 2009; Neumark, Cunningham and Siga, 2006; Carneiro and Corseuil, 2001; Fajnzylber, 2001), Chile (Montenegro and Pages, 2004); Colombia (Maloney and Nunez, 2004, Arango and Panchon, 2004), Costa Rica (Gindling and Terrell, 2005 and 2007); Honduras (Gindling and Terrell, 2009 and 2010), Indonesia (Rama, 2001), Kenya (Andalon and Pages, 2008), Mexico (Bosch and Manacorda, 2010; Cunningham and Siga, 2006); Turkey (Ozturk, 2006),Trinidad and Tobago (Strobl and Walsh , 2001), and South Africa (Hertz, 2005).

${ }^{2}$ These include studies of the impact of minimum wages in developing economies on: wages and the distribution of wages (Andalon and Pages, 2008; Bosch and Manacorda, 2009; Cunningham, 2007; Hertz, 2005; Lemos, 2009; Maloney and Nunez, 2004; Neumark, Cunningham and Siga, 2006, Stroble and Walsch, 2001; Fanzylber, 2001), employment, unemployment and hours worked (Carneiro and Corseuil, 2001; Gindling and Terrell, 2007 and 2009; Hertz, 2005; Lemos, 2009; Maloney and Nunez, 2004; Montenegro and Pages, 2004; Ozturk, 2006; Rama, 2001), part-time and full-time work (Ozturk, 2006), the formal and informal sectors (Andalon and Pages, 2008; Bosch and Manacorda, 2010; Gindling and Terrell, 2007 and 2009; Maloney and Nunez, 2004), and poverty (Arango and Panchon, 2004; Gindling and Terrell, 2010; Lustig and McLeod, 1997; Saget, 2001).
} 
sector, but also result in a reduction in new hires into the covered sector from the uncovered sector. Third, we examine the impact of changes in minimum wages on the movement of workers (transitions) between the covered sector, public sector, selfemployment, unpaid family work, unemployment and out of the labor force. For example, we show that in Nicaragua workers who lose covered sector employment because of higher minimum wages are likely to become unpaid family workers or leave the labor force (and not become self-employed or unemployed). Fourth, we analyze the impact of higher minimum wages on transitions into and out of poverty. We present evidence that higher minimum wages in Nicaragua increase the probability that a poor worker's family will move out of poverty. We also present evidence that the impact of minimum wages differs between household heads and non-heads, and explain how these differences affect the impact of minimum wages on poverty. Panel data is essential in allowing us to make these unique contributions to the literature because, in addition to allowing us to control for individual-specific fixed effects, it is only with panel data that we can identify employment transitions and changes in the incomes of the same individuals or households both before and after the minimum wage change. The individual-level panel data set that we use was created for this study from an existing household-level panel data set in Nicaragua.

\section{Data}

To study the impact of minimum wages on the labor market in Nicaragua, we use annual panel data collected by Fundación Internacional para el Desafío Económico Global (FIDEG) between 1998 and 2006. ${ }^{3}$ This data set is based on a 1996 FIDEG household survey of 6,028 dwellings, which is considered to be representative of the population of households in Nicaragua. The households were selected using stratified random sampling techniques and information on the location of all dwellings in each electoral district of the country. ${ }^{4}$ The 1998 survey is based on a random sub-sample of 1,600

\footnotetext{
${ }^{3}$ FIDEG is an independent public policy research institute in Nicaragua that carries out policy oriented research on Nicaragua's socio-economic development.

${ }^{4}$ The method used was to first randomly select 58 (out of a total of 156) municipalities, based on their share of the total population and fulfilling a quota of 50\% urban. Electoral districts within
} 
dwellings (816 urban and 784 rural) from the 1996 survey. The principal household in each of these dwellings was interviewed annually between the months of July and September from 1998 to 2006.

Enormous care was taken to track each household and each member of the household over this period. For example, the interviewer first determined if the household was interviewed the previous year or if this was its first interview. ${ }^{5}$ The questionnaires had the first and last names of each household member interviewed the previous year, with a designated line item for all years (i.e., that could never be occupied by any other household member). If a member was no longer in the household, questions were asked about that person's location in order to catch migration flows. On the other hand, new household members were designated a line in the questionnaire along with an explanation about their origin in the household (by marriage, birth, etc.).

Our analytical sample consists of 27,000 observations on 8,682 working age individuals (an average 3.1 observations each). About one-third of the sample has two observations, one-fifth has three observations and 7 percent have nine observations. The Appendix Table A1 contains descriptive statistics on our analytical sample.

Given that the panel data is based on a small sample, we have checked its representativeness by comparing some basic characteristics of the workforce with those of the Nicaraguan LSMS survey carried out by the World Bank in 1998 and 2005. We find that the distribution of the economic activity of the workers is quite similar for the two samples in 1998 but there is some divergence in the two 2005 samples as there is a higher share in the tertiary sector in the FIDEG sample. There seems to be a higher share of unpaid family workers in the FIDEG sample and whereas the average incomes look

each municipality were then selected randomly and dwellings were then selected randomly within each district. Within each dwelling, the "principal" household was interviewed.

${ }^{5}$ If the original household left the dwelling (e.g., migrated) it was replaced with the new household in the dwelling, with an indication that it was a new household. If the dwelling was destroyed, the dwelling next door was selected, with an indication that this was a new dwelling/household. 
lower, the median incomes are very similar for the two samples. See Appendix Table A2 for further detail.

The second source of data used is the legal minimum wage decrees from the Nicaraguan Ministry of Labor. Nicaragua sets minimum wages for all workers in the private sector for each of twelve industrial sectors, plus separate minimum wages for workers in freetrade zones (special regimes) and in the central and municipal government. During the years for which we have panel data, new minimum wages are set every year except for 1998 and 2000. Table 1 summarizes the changes in the hourly legal minimum wage for the years we analyze. ${ }^{6}$

We assign to each worker in the FIDEG panel data set a minimum wage based on his/her industry of employment. This implies that we cannot assign a minimum wage to workers who are not in the labor force or to those unemployed people who have not worked before. Further, we cannot identify workers in free-trade zones, nor can we distinguish central and municipal government workers from workers in state-owned firms (for whom the private sector minimum wage applies); therefore we assign to these workers the minimum wage that is applicable to the private sector industry in which they work. We assign to full-time workers (working 40 or more hours a week) a monthly and hourly minimum wage (calculated as indicated in the previous footnote) and to part-time workers only an hourly minimum wage.

We find that the minimum wage is high relative to the mean and median wages of private sector workers during the period that we study. The ratio of the mean minimum wage to the mean wage is 0.53 and the ratio to the median wage is 0.81 . The trend over this period is fairly constant, with dips in 1998 and 2000, when the minimum wage was not changed.

\footnotetext{
${ }^{6}$ Legal minimum wages in Nicaragua are published as monthly earnings for full-time workers and as hourly and daily wages for part-time workers. The daily wage is calculated by the Ministry of Labor as the monthly minimum wage divided by 30.4. The Labor Code considers holidays and Sundays to be working days, hence 30.4 is the average number of formal working days per month. The hourly minimum wage is then calculated as the daily wage divided by 8 .
} 


\section{Compliance Issues}

The law decrees that all private and public sector employees in Nicaragua be paid at least the minimum wage. The workers not covered by minimum wage legislation are the selfemployed (who include the owners of small firms) and unpaid family workers; these workers compose the uncovered sector. Before examining the impact of minimum wage legislation, it is important to detect the sectors of the labor market where there is compliance with minimum wage legislation. There are several ways in which we check for compliance in the data.

\subsection{Comparing the Distribution of Wages and Legal Minimum Wages}

A straightforward method is to look for spikes in the wage distribution at or around the minimum wage. Given the multiple minimum wages in Nicaragua, we simplify the graphical analysis by plotting the kernel density estimate of the log wage minus log minimum wage for each worker. In these figures a zero indicates that the worker is earning the legal minimum wage. To test for different levels of compliance, we construct these figures for five different groups: the total covered private sector, large firms in the covered private sector, small firms in the covered private sector, the covered public sector, and the uncovered self-employed. The rationale for analyzing three groups in the covered sector separately is to decipher the extent to which the small scale sector complies with minimum wages, and to separate out the public sector workers, who tend to have higher wages in most Central American countries.

To construct the kernel density estimates, for full-time workers we compare monthly earnings to the monthly minimum wage. For part-time workers, we compare the hourly wages to the hourly minimum wage. The kernel density estimates are presented in Figure 1, with the same scale to make comparisons between sectors easier. A value above (below) zero indicates that those workers earn above (below) the legal minimum wage. These figures suggest that legal minimum wages have some impact in the covered private sector and in the public sector. In those two covered sectors we see spikes in the 
distribution near zero and the distributions show some evidence of censoring below the minimum wage. However, the evidence of censoring is not strong; a large proportion of workers in the covered sectors earn less than that minimum wage. The censoring and spike near zero in the distribution in the covered private sector are more pronounced for large private sector firms than for small covered private sector firms. This might suggest that compliance is greater in large private sector firms than in small private sector firms. In the uncovered self-employed sector there is no evidence of censoring, but there is a set of spikes in the distribution near the minimum wage.

There is a question as to whether Figure 1 is not capturing compliance cleanly because of potential measurement error in the hourly wage and hourly minimum wage variables that we use for part-time workers. (This is because the hourly measures are calculated from monthly measures that are divided by reported number of hours worked, which can have substantial measurement error.) As a result, we also provide kernel density estimates for subsample of full-time workers only in Figure 2. It is clear from these estimates that the findings in Figure 1 hold; they are not sullied by measurement error.

In summary, the kernel density estimates provide some evidence of compliance with minimum wages in the covered sector, especially large firms, in Nicaragua, and noncompliance in the uncovered (self-employed) sector. However, this evidence is not strong.

\subsection{Proportion of Workers Earning the Minimum Wage by Sector of Employment}

Another way to summarize the information on compliance is to calculate the average share of workers earning less than the minimum wage, near the minimum wage, or more than the minimum wage within each of these four sectors. We use a bound of $20 \%$ to allow for measurement error so that we are actually measuring the share earning less than 0.8 of the minimum wage, within 0.8 and 1.2 of the minimum wage and more than 1.2 of the minimum wage. These data are presented in Table 2, separately for the private covered, public and uncovered self-employed sectors. We also divide the private covered sector into small and large firms. 
There is some evidence that compliance is greater in the covered private sector than in the uncovered self-employed sector: while $25.5 \%$ of workers in the private covered sector earn within $20 \%$ of the minimum wage, only $15.6 \%$ of self-employed workers earn within $20 \%$ of the minimum wage. While this is evidence that compliance is greater in the covered sector than in the uncovered sector, compliance is far from universal even in the covered sector; it is clear that a significant proportion of workers, even in those sectors legally covered by minimum wages, earn less than the minimum wage: as many as $23 \%$ of the workers in the private covered sector. Even in the public sector $4.1 \%$ of workers earn less than the legal minimum wage.

Because many are surprised by the number of workers in Nicaragua earning less than the minimum wage, even in the large firm sector, and some surmise that it may be due to measurement error in the hourly wage and minimum wage variables, we also calculate these percentages using the monthly wage and minimum wage for the subsample of fulltime workers (who account for approximately about $50 \%$ of all workers). The percentages in the second panel of Table 2 indicate that the proportion of covered sector

full-time workers earning less than the minimum wage is similar to our previous results. Also, the share or full time uncovered self-employed workers earning less than the minimum wage is substantially larger than the share for all self-employed workers (including part-time workers).

\section{Wage and Disemployment Effects in the Covered Sector}

In this section we examine the extent to which increases in minimum wage rates raise wages and expel workers from the covered sector, as predicted by the competitive model of the labor market. 


\subsection{Wage Effects}

We next estimate the elasticity of the wage with respect to the minimum wage in the covered sector. Using the panel data set of workers we estimate the following wage equation on all workers who remain in the covered sector from one year to the next:

$$
\Delta \ln W_{i t}=\alpha_{o}+a_{1} \Delta \ln M W_{I t}+\Delta X_{i t}^{\prime} \beta+a_{2} \Delta \ln G D P_{I t}+\sum_{t=l}^{T} \gamma_{t} Y R_{t}+\mu_{i t}
$$

where the dependent variable, $\Delta \ln W_{I t}$, is the change in the log of real wages of individual $i$ between time $t$ and time $t+1$. The explanatory variables include the change in the log of the real minimum wage between time $t$ and time $t+1$ that applies to that worker's industry category I in time $t, \Delta \ln M W_{I t}$. The coefficient $\alpha_{l}$ is an estimate of the impact on actual wages of changes in the legal minimum wage. Other explanatory variables include the vector $X_{i t}$, of individual specific human capital variables (changes in years of education and whether the worker lives in an urban area) and the change in the log of real valueadded in industry $I$ between time $t$ and $t+1$ (lnGDP). ${ }^{7}$ Finally, to control for endogenous changes in yearly average minimum wages (as well as other year-specific factors such as aggregate supply and aggregate demand changes, or the timing of minimum wage changes) we include a dummy variable for each year, $Y R_{t}$. The estimated standard errors in all regression estimates reported in this paper (wage, employment, transition and poverty equations) are robust to heteroskedasticity and correct for clustering of the errors in the industry of the worker (which also corresponds to the minimum wage category).

In addition to estimating the wage equations for individuals who are in the covered sectors at time $t$ and time $t+1$, we also estimate the wage equations for those who remain self-employed from one year to the next as a placebo test. If minimum wages are being enforced in the covered sectors but not the uncovered sector, then changes in the minimum wage should positively affect the wages of those who remain in the covered

\footnotetext{
${ }^{7}$ Note that since we are estimating a model based on first-differencing the individual-level data, the characteristics of individuals that do not change over time (such as gender), or change by the same amount each year (such as age or experience) are already controlled for and cannot be explicitly included in this regression.
} 
sector and have no direct positive effect on the wages of those who remain self-employed from $t$ to $t+1 .^{8}$

Since we expect that legal minimum wages will have a larger impact on the wages of workers who earn near the minimum wage, we also estimate the impact of minimum wages on the wages of workers who were within $20 \%$ of the legal minimum wage at time $\mathrm{t}$ (before the minimum wage was changed).

Finally, we estimate equation (1) for the groups mentioned above with the hourly minimum wage and hourly wage data for all workers (both full-time and part-time workers) and also for those workers within $20 \%$ of the minimum wage at time t. We also estimate the wage equation using the monthly wage and monthly minimum wage for only full-time workers who were within $20 \%$ of the minimum wage at time $t$, to control for measurement error. ${ }^{9}$

\footnotetext{
${ }^{8}$ Even if legal minimum wages are not complied with among the self-employed, it is possible that higher legal minimum wages in the covered sector could have an indirect impact on wages in the self-employed sector. For example, higher legal minimum wages in the covered sector could cause reduced employment in that sector, pushing workers into self-employment, increasing the supply of labor in that sector and driving down the wages of the self-employed.

${ }^{9}$ Another potential problem in the estimation of the wage equation is a violation of the strict exogeneity assumption. In the estimate of first difference equations, the strict exogeneity assumption is violated if there is feedback from the dependent variable in period $t$ to an independent variable in a future period (Wooldridge, 2002). This may occur in our estimates of the wage equation, for example, if a bad (or good) wage shock in the past year affects decisions to increase education. For example, a higher wage in time $t$ might make it affordable for a low-income worker to complete higher education in time s>t. Such feedback can be captured by including a lagged dependent variable in the regression (Wooldridge, 2002). However, the presence of a lagged dependent variable as an explanatory variable in the estimated growth equation creates a potential bias, as the lagged dependent variable will be correlated with the error term in the regression. Arellano and Bond (1991) develop a dynamic panel data model that addresses the problems of the correlation between the lagged dependent variable and the error terms (and also the potential problem of first-order autocorrelated errors). The Arellano and Bond "difference GMM" model estimates the regression using first differences, and uses the values of the levels of the exogenous variables lagged two or more periods as additional instruments for the potentially endogenous independent variables (in addition to the temperature variables used in the 2SLS-IV). We follow Arellano and Bond (1991) and use the simplest two period lag structure in constructing the instrumental variables. In these regressions (available from the authors), the coefficients on the minimum wage variable in all of the equations estimated using data from the private covered sector are positive, although the estimates are statistically significant only for workers in small private covered sector firms. The coefficient on the minimum wage variable using data from self-employed workers is always negative, although is only statistically significant for full-time workers with wages near the minimum wage.
} 
The estimated coefficients for these regressions are reported in Table 3. They can be interpreted as elasticities - the percent change in actual wages given a one percent change in the legal minimum wage - and as evidence for compliance with the minimum wage laws. The estimates of the coefficients on the minimum wage variable do provide evidence that legal minimum wages are complied with in the private covered sector. The coefficients are positive, although statistically significant only for those workers whose wages were near the minimum wage. We estimate an elasticity of 0.58 for all covered private sector workers whose wages are within $20 \%$ of the minimum wage in time $t$, which rises to 0.65 for full-time covered sector workers whose wages are within $20 \%$ of the minimum wage. The estimated elasticities are positive for both large and small firms and statistically significant for full-time workers near the minimum. The relative size of these coefficients also indicates that the impact of the minimum wage may be felt more in the large-firm private sector than in the small-firm private sector, although the difference in the coefficients is not statistically significant. There is no statistically significant impact of minimum wage changes on the wages of private sector workers whose wages are not within $20 \%$ above the minimum wage (not shown in table). The coefficient on the minimum wage variable in the wage equations for uncovered self-employed workers is never statistically significant, indicating that legal minimum wages are not complied with in this sector. ${ }^{10}$

In summary, the wage equations suggest that minimum wage laws in Nicaragua are complied with in the private covered sector, but do not have a significant impact on the wages of workers in the uncovered self-employment sector. ${ }^{11}$

\footnotetext{
${ }^{10}$ Since we are unable to assign the correct minimum wage for workers in the FIDEG survey that say they work for the public sector, but do not indicate if they work for a state-owned enterprise or public administration, we have not analyzed the impact of the minimum wage on their wages.

${ }^{11}$ As a specification test, we re-estimated the wage equations including industry dummy variables as explanatory variables. These results are generally similar to those reported in table 3 . As another specification test, we re-ran the wage equations including lagged values of the minimum wage variables. In these regressions with lagged independent variables the coefficients on the lagged values were almost always insignificant. In the one case where coefficient on the lagged value was not insignificant, it was the same sign as the coefficient on the concurrent value. This was in the transition equation for unpaid family workers, and indicated once again that workers who lose their jobs in the covered sector are more likely to
} 


\subsection{Disemployment Effects}

We next examine the impact of changes in minimum wages on the employment of workers in the private covered sectors. Using the panel data set of workers and binomial probit analysis, we estimate, for all workers who were in the private covered sectors at time $t$, the following employment equations:

$$
\operatorname{Prob}\left(E M P_{i t}=1\right)=\alpha_{o}+a_{1} \Delta \ln M W_{I t}+\Delta X_{i t}^{\prime} \beta+a_{2} \Delta \ln G D P_{I t}+\sum_{t=1}^{T} \gamma_{t} Y R_{t}+\mu_{i t},
$$

where the dependent variable, $\operatorname{Prob}\left(E M P_{i t}=1\right)$ is equal to one if individual $i$ remains employed in the covered sector between time $t$ and time $t+1$, and zero if individual $i$ loses his/her private covered sector employment between time $t$ and time $t+l$ (and ends up either as a self-employed worker, unpaid family worker, unemployed or out of the labor force). The explanatory variables are the same as those in the wage equation. From the coefficient $\alpha_{1}$ we can estimate the impact on the probability that a worker remains employed in the private covered sectors of a change in the legal minimum wage.

Our estimates of the impact of changes in legal minimum wages on the probability that a worker remains in the private covered sector are reported in Table 4. A negative number in Table 4 indicates that an increase in minimum wages reduces the probability that a worker keeps his/her employment in the private covered sector (that is, a negative number indicates that higher minimum wages increase the probability that a worker will lose his/her private covered sector employment). These results imply that an increase in the legal minimum wage will result in a statistically significant fall in employment in the private covered sector; a $10 \%$ increase in the legal minimum wage will result in a decrease in the probability that a worker remains in the private covered sector by 3.1 percentage points for all workers, a decrease of $5.2 \%$ for all workers with wages near the minimum wage, and a similar $5.1 \%$ fall in full-time employment near the minimum. Evaluated at the average proportion of workers in the private covered sector, these results imply that a $10 \%$ increase in the legal minimum wage results in approximately $5 \%$ of private covered sector employees losing employment in that sector. We find a 
statistically significant negative employment impact of increases in minimum wages in large, but not small, private covered sector firms.

In summary, our evidence is consistent with the hypothesis that increases in legal minimum wages in Nicaragua result in private covered sector workers losing their private sector employment, and that the decline is larger and statistically significant in the largefirm private sector where wage impact of the minimum wage - i.e., compliance -- is stronger.

\section{Dynamic Effects: Employment Transitions}

Higher minimum wages can lead to decreased employment in the private covered sector either because workers lose their private covered sector jobs and/or because fewer workers are hired into the private covered sector. An original contribution of our work, which is possible because of the panel data that we create, is to trace the impact of minimum wages on employment flows into and out of the private covered sector, and from the private covered sector into other sectors (e.g., self-employed) and status in the labor market (unemployment and the labor force). In sub-section 4.2 we showed that higher minimum wages lead to some workers losing private covered sector employment. In this subsection, we first examine where workers go who leave the private covered sector because of a minimum wage increase (e.g. into self-employment, the public sector, unemployment, unpaid family work, out of the labor force). Then we examine whether there is evidence that an increase in the minimum wage also reduces employment in the private covered sector by lowering rates of new hiring into the private covered sector from the uncovered sectors.

We first estimate a multinomial logit model using the sample of all workers employed in the private covered sector at time $t$, where it is possible for workers who start in the private covered sector to be found in one of the following sectors in time $t+1$ : stay in the

private covered sector, move to self-employment, move to unpaid family work, move to from the authors at http://userpages.umbc.edu/ tgindlin/publications.html. 
the public sector, become unemployed or leave the labor force. Specifically, we define a variable, TRANS $\mathrm{T}_{\mathrm{ikz}, \mathrm{t}}$, that indicates whether the worker moves from sector $\mathrm{k}$ (the private covered sector) into sector $\mathrm{z}(\mathrm{z}=$ stay in the private covered sector, self-employment, unpaid family work, the public sector, unemployment or leave the labor force). The base category is that a worker stays in the private covered sector. Thus, the probability that individual i leaves the private covered sector (sector $\mathrm{k}$ ) for sector/state $\mathrm{z}$, conditional on starting in sector $\mathrm{k}(\mathrm{k}=$ private covered sector, self-employed sector, unpaid family work, the public sector, unemployment or leave the labor force) is characterized by:

$$
\operatorname{Prob}\left(T R A N S_{i k z, t}=1\right)=\exp \left(\theta_{i k z, t}\right) /\left(1-\exp \left(\left(\theta_{i k z, t}\right)\right)\right.
$$

where

$$
\theta_{k k, t}=\alpha_{o k z}+a_{1 k z} \Delta \ln M W_{I t}+\Delta X_{i t}^{\prime} \beta_{k z}+a_{2 k z} \Delta \ln G D P_{I t}+\sum_{t=1}^{T} \gamma_{z t} Y R_{t}+\mu_{i k z, t}
$$

The explanatory variables include the change in the log of the real minimum wage that applies to that worker's industry I at time t, $\Delta M W_{I t}$. The impact of minimum wages on the probability of moving from the private covered sector into sector $\mathrm{z}$ is measured using $\alpha_{1 z}$. We calculate the marginal impact of changes in legal minimum wages on the probability that workers leave the private covered sector and go into the public sector, self-employment, unpaid family worker sector, unemployment or leave the labor force. Other explanatory variables are the same as those in the wage and employment equations.

Table 5 presents our estimates of the marginal impact of changes in legal minimum wages on the probability that workers leave the private covered sector and go into another sector; a positive number in Table 5 means that higher minimum wages increase the probability that a worker leaves his/her job in the private covered sector and moves to sector z. The results suggest that workers in the private covered sector lose their jobs when minimum wages increase, and that they are likely to become unpaid family workers. This is a novel and robust result; it is true whether we use the sample of all workers, those within $20 \%$ of the minimum wage or full-time workers near the minimum wage. The effect is quite large, especially for full-time workers near the minimum wage, 
where a $1 \%$ increase in the minimum wage will increase the probability that a worker moves from the private covered sector to unpaid family work by 0.42 percentage points. Given that the mean (unconditional) probability is $4.2 \%$, a $1 \%$ increase in the minimum wage will raise the probability to $4.6 \%$ (a 9 percent increase). There is also evidence that other workers who leave the private covered sector may leave for a public sector job or leave the labor force; however, there is no evidence in Table 5 that workers who lose their jobs in the private covered sector move into self-employment or unemployment. ${ }^{12}$

Next, we also estimate the effect of minimum wages on the probability of being hired into the private covered sector from self-employment, unpaid family work or the public sector. We first estimate the "overall" effect on hires from any of these sectors, and then the "specific" effect on hires from a specific sector (public sector, self-employment or unpaid family work ${ }^{13}$ ). Specifically, we use the probit technique to estimate equations of the form:

$$
\operatorname{Prob}\left(T R A N S_{i k z, t}=1\right)=\alpha_{o k z}+a_{l k z} \Delta \ln M W_{I t}+\Delta X_{i t}^{\prime} \beta_{k z}+a_{2 k z} \Delta \ln G D P_{I t}+\sum_{t=1}^{T} \gamma_{z t} Y R_{t}+\mu_{i k z, t}
$$

For the overall effect, the dependent variable, $T R A N S_{i k z, t}$, equals 1 if the individual $i$ is hired into the covered private sector at time $t+1$ from any other sector at time $t$; it is equal to zero if the individual remains in an uncovered sector from $t$ to $t+1$. For the specific

\footnotetext{
${ }^{12}$ The minimum wage has less of an effect on flows from private sector work to out of the labor force: a $1 \%$ increase in the minimum wage will raise the probability 0.15 percentage points for all workers and 0.21 for workers earning around the minimum wage. For all workers, this means raising the mean unconditional probability from $21.9 \%$ to $22.1 \%$, which represents only a 0.6 percent increase. For workers near the minimum wage the mean probability would rise from $21.1 \%$ to $21.3 \%$ (or by 1.0 percent).

Our results suggest that there is clearly a drop in income for private covered sector workers who were near the minimum wage and lost their jobs, since most became unpaid family workers or left the labor force (where they no longer earn any wage). However, given there is evidence that some workers are instigated to move to the public sector when there is an increase in the minimum wage, we next test for the wage effect on these workers. We estimate wage equation (1) on workers who leave the private covered sector and end up working as public sector workers in time $t+1$ and in this way, we are able to estimate whether those who change jobs after minimum wage changes end up with lower wages in the public sector. The findings show that those who move to the public sector do not have a significant change in their earnings.

${ }^{13} \mathrm{We}$ cannot measure whether legal minimum wages affect the transitions from unemployment and out of the labor force into the private formal sector because we do not know the industry of employment of those who are unemployed or not in the labor force in both time $t$ and time $t+1$.
} 
effects, TRANS $S_{i k, t,}$ equals 1 if the individual $i$ is hired into the covered private sector at time $t+1$ conditional on being in another specific sector (e.g., self employment) at time $t$; it is equal to zero if the individual remains in the other specific sector from $t$ to $t+1$.

Table 6 presents these estimates; a positive number in Table 6 would indicate that higher minimum wages increase the probability of a transition into the private covered sector from the self-employed, public or unpaid family worker sectors, while a negative number indicates that higher minimum wages decrease the probability that a worker will transition into the private covered sector. The results imply that an increase in the legal minimum wage has a negative and statistically significant impact on the probability that a worker will be hired into the private covered sector from the public sector or selfemployment. The marginal effect is large. A $1 \%$ increase in the minimum wage lowers the probability that a either a self-employed or public sector worker at time $t$ will be hired into the private covered sector at $\mathrm{t}+1$ by 0.52 percentage points for all workers within $20 \%$ of the MW. We find no evidence that higher minimum wages have an impact on the transition from unpaid family work into the private covered sector.

In summary, the results of the estimation of the transition equations suggests that the decrease in employment in the private covered sector that results from a higher legal minimum wage is due both to workers leaving the private covered sector and to a reduction in the number of workers being hired into the private covered sector from the uncovered sectors. Most workers who lose their jobs in the private covered sector as a result of higher legal minimum wages leave the labor force or go into unpaid family work; a smaller proportion may find work in the public sector. We find no evidence that workers who lose their jobs in the private covered sector because of higher minimum wages become unemployed. ${ }^{14}$

\footnotetext{
${ }^{14}$ As a specification test, we re-ran the employment and transition regressions including lagged values of the minimum wage and the coefficients on the lagged values were almost always insignificant. In the one case where coefficient on the lagged value was not insignificant, it was the same sign as the coefficient on the concurrent value. This was in the transition equation for unpaid family workers, and indicated once again that workers who lose their jobs in the covered sector are more likely to become unpaid family workers than to go into any other sector. These results are available from the authors (at http://userpages.umbc.edu/ tgindlin/publications.html).
} 


\section{Effects on Household Income and Poverty Alleviation}

The impact of legal minimum wages on households at different points in the distribution may be different from the impact on the distribution of wages. Low wage workers may be secondary family workers in high income households while high wage workers may be the only workers in low wage households. As Addison and Blackburn (1999) and Fields, Han and Kanbur (2007) point out, the impact of legal minimum wages on household incomes depends on how the pattern of employment composition changes within households. We cannot, therefore, infer from our results on the impact of minimum wages on individual wages and employment what the impact will be on either the distribution of household income or poverty alleviation. We must study directly the impact of legal minimum wages on household incomes.

Minimum wage increases can help families move out of poverty if the family members keep their jobs and benefit from a wage increase, but they may be just as likely to stay poor (or become poor) if a family member affected by a minimum wage increase loses his/her job. In this section we first examine the impact of minimum wages on the probability that a worker's family is poor, and then examine the extent to which a minimum wage increase helps a family move out of poverty or push a family into poverty. Given the importance of the head of the household's income in the total income of the family, ${ }^{15}$ we carry out an analysis that distinguishes the effect of minimum wage on the head and non-heads of the household.

We first ask to what extent workers who earn the minimum wage are likely to be poor. The numbers in Table 7 indicate that if a household head is earning at or above the minimum wage, he/she is very likely to be in a non-poor household: $57 \%$ of the heads of households who earn around the MW are non-poor and $81 \%$ of the heads who earn above the minimum are non-poor. However, if a non-household head is earning at or above the minimum wage, he/she is much less likely to be in a non poor household, where the

\footnotetext{
15 The head of the household's labor income accounts on average for $74 \%$ of the household's income; in poor households it rises to $81 \%$ and in non-poor households it is only $55 \%$.
} 
comparable percentages are $37 \%$ and $58 \%$. Finally, both heads and non-heads of households are likely to be extremely poor or poor if they earn below the minimum wage.

These results in Table 7 are a static picture of the probability that a worker is poor or non poor based on status in the household and the ratio of own wage to the minimum wage. We next ask "What is the impact of a change in the minimum wage on the probability that a household is poor?" We answer this question using the panel data and estimating a probit equation using data for all workers, where the dependent variable is equal to 1 if the worker's household is poor at $t+1($ Poor $=1)$ and 0 if non poor at time $t+1($ Poor $=0)$, as a function of the change in the minimum wage from the period $t$ to $t+1$ :

$$
\operatorname{Prob}\left(P_{O O O R}=1\right)=\alpha_{o}+a_{1} \Delta \ln M W_{I t}+\Delta X_{i t}^{\prime} \beta+a_{2} \Delta \ln G D P_{I t}+\sum_{t=l}^{T} \gamma_{t} Y R_{t}+\mu_{i t},
$$

From the coefficient $a_{l}$ we calculate the impact of a one percent change in the minimum wage on the probability that a worker's family is poor. The other variables in this equation are the same as those in equations (1) through (4).

The results from this exercise, presented in Table 8, indicate that an increase in the minimum wage will significantly lower the probability that a household is poor, but only if the higher minimum wage applies to the household head; minimum wage increases for non-household heads have an insignificant impact on the incidence of poverty. The marginal effect (where all variables are taken at their mean values) of a $1 \%$ increase in the minimum wage lowers the incidence of poverty by 0.12 percentage points if it impacts a head. Further, higher minimum wages have a significant positive impact only on families with more than one worker at time t. Possibly this is because the minimum wage is set very low relative to the poverty line for a family, who are therefore likely to transition out of poverty only if the family receives income from at least two workers. The impact of a minimum wage increase does not differ significantly between male and female household heads.

Up to now we have determined that changes in the minimum wage reduce the incidence of poverty if they impact heads of households with certain characteristics, but do they 
actually help households transition out of poverty? Moreover, it might be possible that households with certain characteristics may be more likely to transition into poverty if some members lose their jobs as a result of the minimum wage increase. In the next exercise, we estimate the impact of a change in the minimum wage on the probability that a poor household at time $t$ becomes non-poor at time $t+1$ and vice versa, that a non-poor household at time $t$ becomes poor at $t+1$. Specifically, we estimate two poverty transition equations. In the first, using a sample of workers in poor households in time $t$, we estimate a probit equation of the form:

$\operatorname{Prob}\left(O U T P O V_{i t}=1\right)=\alpha_{o}+a_{1} \Delta \ln M W_{I t}+\Delta X_{i t}^{\prime} \beta+a_{2} \Delta \ln G D P_{I t}+\sum_{t=1}^{T} \gamma_{t} Y R_{t}+\mu_{i t}$,

In equation 6, OUTPOV it equals one if the family of worker $i$ is poor in time $t$ but not poor in time $t+1$, and zero if the family of worker $i$ is poor at time $t$ and stays poor in time $t+1$. The independent variables include the change in the log of the minimum wage applicable to the worker's job in time t. The coefficient on this minimum wage variable, $a_{1}$, allows us to measure the impact of an increase in the minimum wage on the probability that a worker's household will move out of poverty. We estimate the impact of minimum wages on the transition out of poverty separately for household heads and non-heads, and for household heads with different characteristics. The other variables in equation (6) are the same as those in the employment transition equations.

Next, using a sample of workers in non-poor households in time $t$, we estimate a probit equation of the form:

$$
\operatorname{Prob}\left(I N P O V_{i t}=1\right)=\alpha_{o}+a_{1} \Delta \ln M W_{I t}+\Delta X_{i t}^{\prime} \beta+a_{2} \Delta \ln G D P_{I t}+\sum_{t=l}^{T} \gamma_{t} Y R_{t}+\mu_{i t},
$$

In equation 7, INPOV $\mathrm{V}_{\text {it }}$ equals one if the family of worker $\mathrm{i}$ is not poor in time $t$ but is poor in time $t+1$, and zero if the family of worker $i$ is not poor at time $t$ and stays not poor in time $t+1$. The independent variables include the change in the log of the minimum wage of applicable to the worker's job in time t. The coefficient on this variable, $a_{l}$, allows us to measure the impact of an increase in the minimum wage on the probability that a family that was not poor will become poor. We estimate the impact of minimum wages on the transition into poverty separately for household heads and non-heads, and 
for household heads with different characteristics. The other variables in equation (7) are the same as those in the employment transition equations.

The results of the estimation of equations (6) and (7) are presented in Table 9. The findings in Table 9 indicate that increases in the minimum wage will pull households out of poverty but will not throw households into poverty. We find that the marginal effect of an increase in the minimum wage has no statistically significant impact on the probability that a worker in a non-poor household becomes poor in the next period, irrespective of the characteristics of the household. On the other hand, a 1\% increase in the minimum wage will increase the probability that a worker in a poor household at $t$ will become non-poor at $t+1$ by 0.12 percentage points. Higher minimum wages help pull families out of poverty only if the higher minimum wage applies to the head of the household; a higher minimum wage for a non-household head has an insignificant impact on the probability that a poor family will leave poverty.

We have found that higher minimum wages in Nicaragua increase the probability that a household will transition out of poverty, even though higher minimum wages lead to decreases in employment in the private covered sector. Further, we found that the positive impact of minimum wages on the transition out of poverty occurs only if the minimum wage increases for the household head; increases in minimum wages for nonheads do not improve the chances that a household will leave poverty. This suggests that the negative impact of higher minimum wages on private covered sector employment might be less for household heads compared to non-heads. If employers in Nicaragua tend to be paternalistic, they may be more likely to keep a worker that they know is the head of a household with dependents rather than a worker that they perceive as a secondary earner, whose income is less important for the household. Hence we next reestimate equations as in Tables 4 and 5, but distinguishing whether the worker is the head of the household or not.

We find support in Table 10 for the hypothesis that, faced with an increase in minimum wages, private covered sector employers in Nicaragua tend to layoff non-heads of 
household more easily than heads of households. Although Table 10 presents evidence that both household heads and non-heads are more likely to lose their employment in the private covered sector when minimum wages increase, the marginal effect is nearly twice as large for non-heads as heads. ${ }^{16}$

Further, the destination sectors for those workers who lose their employment in the private covered sector because of higher minimum wages differ between household heads and non-heads. In Table 11 we present the marginal effects of the same equation estimated in Table 5 but for heads v. non-heads of household. Non-heads who leave the private covered sector are most likely to become unpaid family workers or to leave the labor force (and therefore do not receive any wage), while household heads who leave the private covered sector are most likely to become self-employed (where they are still making income). ${ }^{17}$ Thus, when minimum wages cause workers to lose their employment in the private covered sector, the negative impact on family income is much greater if the worker is a non-head compared to a household head. Given the relative size of their incomes, the fact that the head of the household is able to replace some portion of his/her income with self-employment earnings can also help explain why the negative employment effects of higher minimum wages do not push households into poverty.

In the first part of this paper, we found that a $10 \%$ increase in the minimum wage increased the average wage of private covered sector workers within $20 \%$ of the minimum wage by about $5 \%$, but also resulted in about $5 \%$ of private covered sector workers losing employment in the covered sector. We also found that, on average, workers who lost their jobs in the private covered sector were likely to become unpaid family workers or leave the labor force, and thus earn no income. Given the counteracting wage and employment effects, it was surprising that we found that a higher

\footnotetext{
${ }^{16}$ Contrary to our results, Neumark, Cunningham and Siga (2006) find that in Brazil higher minimum wages have a negative impact on the employment of household heads but a small positive impact on the employment and hours worked of non-heads, and Arango and Panchón (2004) find that in Colombia negative employment effects are larger for household heads compared to non-heards.

${ }^{17}$ Note that for non-heads the marginal effect of higher minimum wages on the probability of moving from the private covered sector to self employment is negative and significant, indicating that a higher minimum wage reduces the probability that a non-head will move from the private covered sector into selfemployment.
} 
minimum wage led to a reduction in poverty among households. The solution to this seeming puzzle is the different impacts a higher minimum wage has on household heads and non-heads. Household heads (who in general earn the highest fraction of household income) are less likely than non-household heads to lose their employment in the private covered sector when minimum wages increase. Further, those household heads who do lose their employment in the private covered sector are likely to move into the selfemployed sector and do not see their incomes reduced to zero. On the other hand, nonhousehold heads who lose their employment in the private covered sector become unpaid family workers or leave the labor force, and thus the household suffers a substantial loss in income.

\section{Conclusions}

In this paper we found that in Nicaragua, during the 1998-2006 period, increases in the minimum wage increased the wages and decreased the employment of workers in the private covered sector. However, minimum wages affected only those workers whose initial wage (before the change in minimum wage) was close to the minimum. For example, increases in legal minimum wage rates led to significant increases in the average wages of private covered sector workers who had wages within $20 \%$ of the minimum wage before the change, but had no significant impact on wages in other parts of the distribution. The effects were stronger among workers in large firms than in small firms. We found that employment in the private covered sector fell when minimum wages increased both because increases in minimum wages resulted in workers losing employment in the private covered sector, and also because higher minimum wages resulted in a reduction in new hires into the private covered sector from the uncovered sectors. Most workers who lost their employment in the private covered sector as a result of higher legal minimum wages left the labor force or went into unpaid family work. We found no evidence that these workers became unemployed.

Our analysis of the relationship between the minimum wage and poverty found: a) increases in legal minimum wages increased the probability that a poor worker's family 
moved out of poverty, and b) increases in legal minimum wages were more likely to reduce the incidence of poverty and improve the transition from poor to non-poor if they impacted the head of the household rather than the non-head. This was because a head of household was less likely than a non-head to lose his/her employment in the private covered sector if minimum wages increased, and because those heads who did lose employment were more likely to go to another paying job (in self-employment) than nonheads (who were more likely to go into unpaid family work or leave the labor force). 


\section{References}

Acemoglu D. Good jobs versus bad jobs. Journal of Labor Economics 2001; 19(1); 1-21.

Addison J, Blackburn M. Minimum wages and poverty. Industrial and Labor Relations Review 1999; 52; 393-409.

Andalon M, Pages C. Minimum wages in Kenya. IZA Discussion Paper No. 3390: Bonn; March 2008.

Arango C, Panchon A. Minimum wages in Colombia: holding the middle with a bite on the poor. Colombian Central Bank unpublished paper; Bogotá; 2004.

Arellano M, Bond S. Some tests of specification for panel data: Monte Carlo evidence and an application to employment equations. Review of Economic Studies 1991; 58(2); 277-297.

Bosch M, Manacorda M. Minimum wages and earnings inequality in urban Mexico. American Economic Journal: Applied Economics 2010; 2(4); 128-149.

Carneiro FG, Corseuil, CE. Minimum wage effects on wages and employment: evidence from time series and longitudinal data. IPEA Working Paper No. 849: Brasilia; December 2001.

Cunningham, W. Minimum wages and social policy: lessons from developing countries. The World Bank: Washington; 2007.

Cunningham W, Siga L. Wage and employment effects of minimum wages on vulnerable groups in the labor market: Brazil and Mexico. World Bank/LCSHS: Washington; 2006.

Fajnzylber P. Minimum wage effects throughout the wage distribution: evidence from Brazil's formal and informal sectors. Department of Economics, Universidade Federal de Minas Gerais unpublished paper; Minas Gerais; 2001.

Fields G, Han B, Kanbur R. Poverty effects of the minimum wage: the role of household employment composition. Cornell University unpublished paper: Ithaca; November 2007.

Freeman R. The minimum wage as a redistributive tool. The Economic Journal 1996; $106 ; 639-649$.

Gindling TH, Terrell K. Minimum wages, globalization and poverty in Honduras. World Development 2010; 38(6); 908-918.

Gindling TH, Terrell K. Minimum wages and employment in various sectors in Honduras. Labour Economics 2009; 16(3); 291-303.

Gindling TH, Terrell K. The effects of multiple minimum wages throughout the labor market: the case of Costa Rica. Labour Economics 2007; 14; 485-511.

Gindling TH, Terrell K. Legal minimum wages and the wages of formal and informal sector workers in Costa Rica. World Development 2005; 33(11); 1905-1921.

Heckman J, Pages C. The cost of job security regulation: evidence from the Latin American labor markets. Journal of the Latin American and Caribbean Economic Association 2000; 1; 109-154. 
Hertz T. The effect of minimum wages on the employment and earnings of South Africa's domestic service workers. University of Cape Town Development Policy Research Unit Working Paper 9623: Cape Town; 2005.

Lemos S. Minimum wage effects in a developing country. Labour Economics 2009; 16; 224-237.

Lustig N, McLeod D. Minimum wages and poverty in developing countries: some empirical evidence. In: Edwards S, Lustig N (Eds), Latin America: combining social protection with market flexibility. Brookings Institution: Washington; 1997; p. 62-103

Maloney W, Nunez J. Measuring the impact of minimum wages: evidence from Latin America," In: Heckman J, Pages C (Eds), Law and employment: lessons from Latin America and the Caribbean. University of Chicago Press and National Bureau of Economic Research: Chicago; 2004; 109-130.

Montenegro C, Pages C. Who benefits from labor market regulations? Chile 1960-1998. In: Heckman J, Pagés C (Eds), Law and employment: lessons from Latin America and the Caribbean. University of Chicago Press and National Bureau of Economic Research: Chicago; 2004; 401-434.

Neumark D, Wascher W. Minimum wages and employment: evidence from the new research. NBER Working Paper 12663: Boston; 2006.

Neumark, D, Cunningham W, Siga L. The effects of the minimum wage in Brazil on the distribution of family incomes: 1996-2001. Journal of Development Economics 2006; 80(1); 136-159.

Otzturk O. Employment effects of minimum wages in inflexible labor markets. MPRA Paper No 16233, mpra.ub.uni-muenchen.de/16233 (accessed March 8, 2011): 2006.

Pages C, Micco A. The economic effects of employment protection laws. Paper presented at the IZA/The World Bank Conference on Employment and Development: Berlin; May 2006.

Rama M. What happens when the minimum wage is doubled? Industrial and Labor Relations Review 2001; 54(4); 864-886.

Sagat C. Is the minimum wage and effective tool to promote decent work and reduce poverty? The experience of selected developing countries. ILO Employment Paper 2001/13: Geneva; 2001.

Strobl E, and Walsh F. Minimum wage and compliance: the case of Trinidad and Tobago. Economic Development and Cultural Change 2001; 51(2); 427-450.

Wooldridge J. Econometric analysis of cross section and panel data. The MIT Press: Cambridge; 2002. 


\section{APPENDIX: \\ Relationship Between the Levels of the Poverty Lines and Minimum Wages}

Fields, Han and Kanbur (2007) point out that if the minimum wage is set above the poverty line, then an increase in the minimum wage will not affect the poverty rate (because those whose wage increases because of the minimum wage increase were already non-poor). However, it is complicated by the fact that a poverty line is set for a family and the minimum wage usually is for an individual. However, it turns out that in Nicaragua, one minimum wage is supposed to support an average family; hence this makes comparing the level of the minimum wage to the poverty line a worthwhile exercise.

In Nicaragua there are two sets of poverty lines, one constructed by INEC, the National Institute of Statistics and Census, and the other by FIDEG. In our analysis we use the one by FIDEG, but we think it is instructive to understand how each is constructed and the relationship between the two. In the FIDEG survey the poverty lines are based on the value of a basic basket of 53 goods and services consumed by a family of four adults and two children, which is fixed by the Central Bank of Nicaragua each year. The goods and services in the basket, determined as the basic needs (protein and caloric as well as housing, clothing, transportation, etc.), are valued each year at the market prices. The extreme poverty line is set at the value of one basket while the poverty line is set at the value of two baskets. During the time of our study, the methodology for calculating the basic basket did not change. INEC sets a poverty line based on consumption and using data from the World Banks LSMS in 1998, 2001 and 2005. The extreme poverty line is defined as cost of the annual level of food consumption needed to satisfy the minimum caloric needs of a person, which were determined as 2,187 calories per day in 1998 and 2001 and 2,241 calories per day in 2005. The poverty line was equal to the amount of the extreme poverty line plus an additional sum to cover the cost of consuming essential nonfood goods and services (such as housing, transportation, education, clothing, housing, etc.). 
In Panel A of Table A5 we present the poverty lines (in nominal Córdobas) for poverty and extreme poverty in the years 1998-2006 as calculated by FIDEG and INEC. The first two columns present the data as reported by each institution and in the next two we report the data in comparable terms "monthly income per capita." It is clear from the last two columns of the table that the ratio between the two sources is fairly constant. In each of the three years, the FIDEG per capita poverty and extreme poverty lines are about 40$50 \%$ higher than the INEC poverty lines. Hence, we should be aware that we are using a relatively high poverty line in this study.

In Panel B of Table A5 we compare the minimum monthly minimum wage and the average monthly minimum wage (weighted by the number of workers in the sample in each minimum wage category) to the monthly poverty lines. We do so for both the per capita poverty line (i.e., for one individual) and the poverty line for a family of six individuals, since the law stipulates that the minimum wage should support a family. As we can see from Table 7, panel B, the minimum wage is set well below both the extreme poverty line and the poverty line for a family of 6 . This is true whether we compare the average minimum wage or the minimum minimum wage to the poverty line. The average minimum wage is between $25 \%$ and $42 \%$ of the extreme poverty line for a family of six and between $12 \%$ and $21 \%$ of the poverty line for a family of six. For a family with only one member, the minimum minimum wage is set above the per capita extreme poverty line but below the per capita poverty line, while the average minimum wage is set above both the extreme poverty line and the per capital poverty line. Over time, the minimum wage increases relative to the poverty line. What is clear is that the minimum wage could not possible cover the needs of a family; at best it may cover the minimum basic needs of an individual (although this depends on which minimum wage applies). Therefore, there is clearly scope for higher minimum wages to affect the poverty rate in Nicaragua. 
FIGURES AND TABLES 
Figure 1: Graphs of Log Wage - Log Minimum Wage, All Years and All Workers
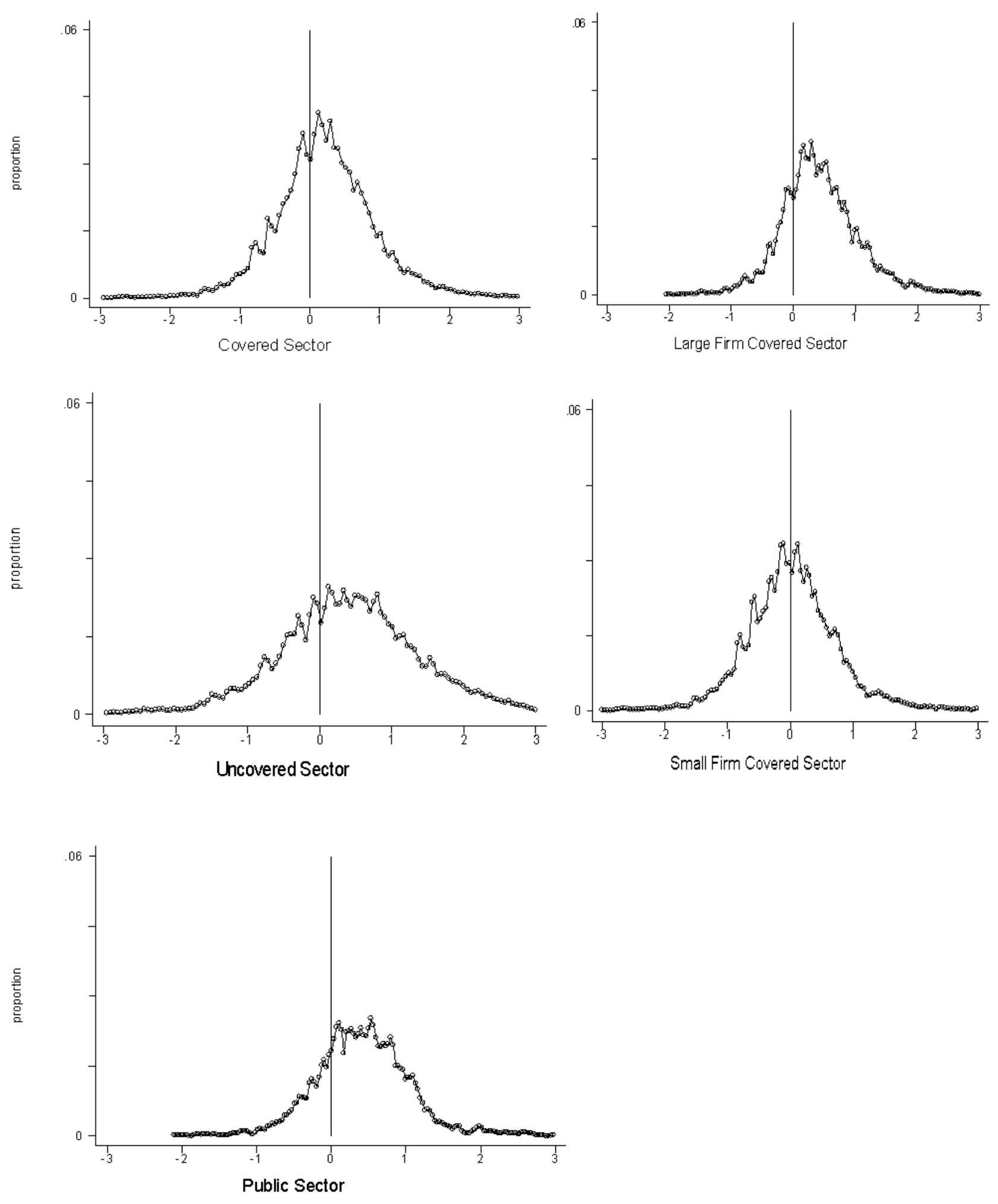
Figure 2: Graphs of Log Wage - Log Minimum Wage, All Years, Full-time Workers Only
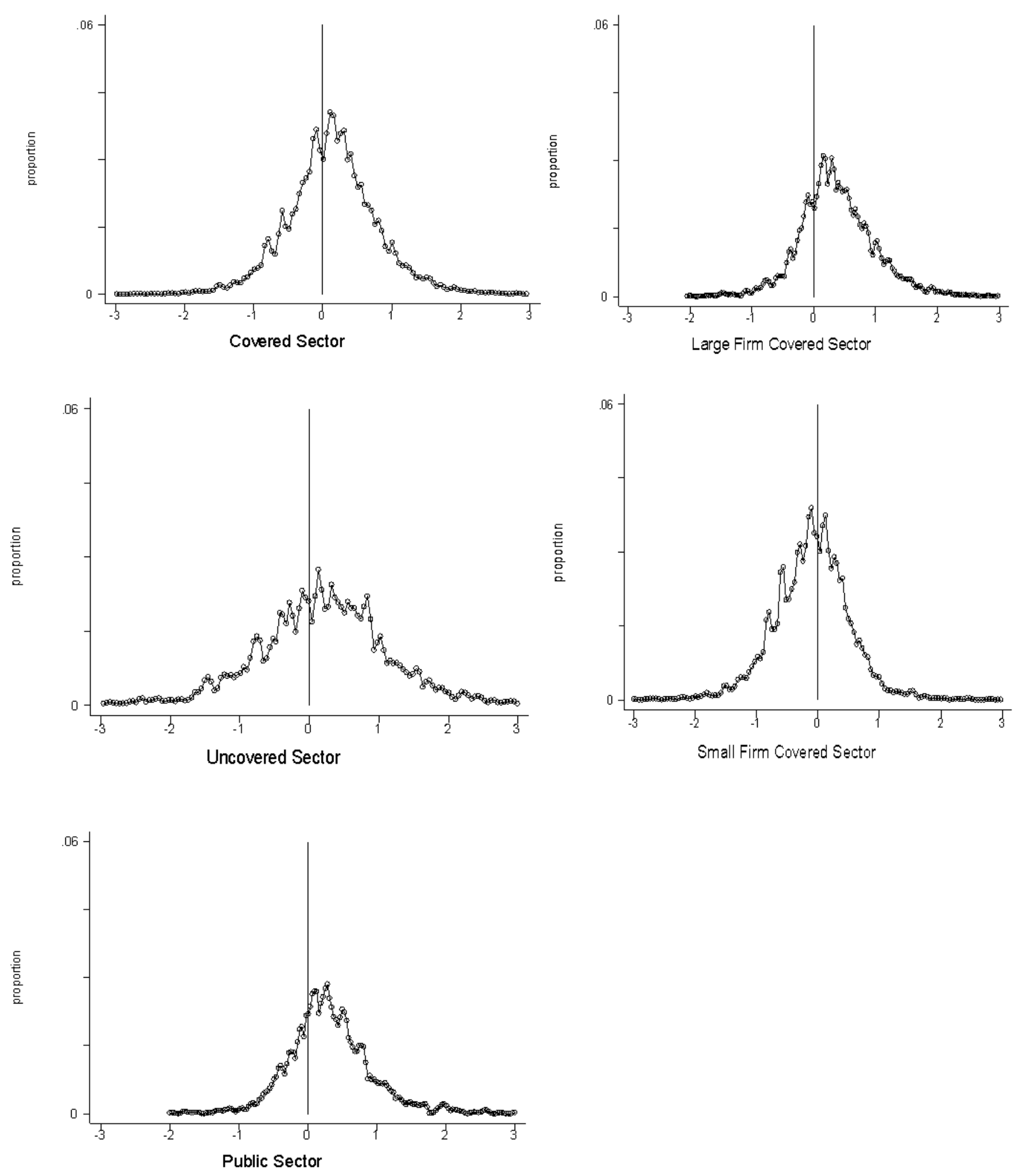
Table 1: Real Minimum Wage (Córdobas per hour) in Nicaragua, 1997-2006

\begin{tabular}{l|c|c|c|c|c|c|c|c|c|c}
\hline \multicolumn{1}{c|}{ Categories } & $\mathbf{1 9 9 7}$ & $\mathbf{1 9 9 8 ^ { * }}$ & $\mathbf{1 9 9 9}$ & $\mathbf{2 0 0 0 ^ { * }}$ & $\mathbf{2 0 0 1}$ & $\mathbf{2 0 0 2}$ & $\mathbf{2 0 0 3}$ & $\mathbf{2 0 0 4}$ & $\mathbf{2 0 0 5}$ \\
Jun & $\mathbf{2 0 0 6}$ \\
May & Mar \\
\hline Agriculture** & 0.90 & -1.79 & 1.08 & 1.00 & 1.14 & 1.17 & 1.18 & 1.17 & 1.23 & 1.26 \\
Fishing & 1.51 & 1.32 & 1.69 & 1.56 & 1.63 & 1.74 & 1.82 & 1.82 & 1.90 & 1.99 \\
Mining & 1.81 & 1.58 & 2.05 & 1.89 & 1.97 & 2.10 & 2.20 & 2.19 & 2.30 & 2.35 \\
Industry & 1.51 & 1.32 & 1.45 & 1.33 & 1.39 & 1.47 & 1.58 & 1.57 & 1.64 & 1.76 \\
Industry under special regime & - & - & 1.93 & 1.78 & 1.86 & 1.93 & 1.98 & 1.98 & 2.07 & 2.14 \\
Electricity and Gas & 1.81 & 1.58 & 2.17 & 2.00 & 2.10 & 2.24 & 2.25 & 2.25 & 2.35 & 2.40 \\
Water & 1.81 & 1.58 & 2.17 & 2.00 & 2.10 & 2.24 & 2.25 & 2.25 & 2.35 & 2.40 \\
Trades, Restaurants and Hotels & 1.66 & 1.45 & 2.17 & 2.00 & 2.10 & 2.15 & 2.25 & 2.25 & 2.35 & 2.40 \\
Transport, storage and communication & 1.36 & 1.19 & 2.17 & 2.00 & 2.10 & 2.24 & 2.25 & 2.25 & 2.35 & 2.40 \\
Construction & 1.45 & 1.27 & 2.90 & 2.67 & 2.70 & 2.75 & 2.77 & 2.77 & 2.93 & 2.93 \\
Financial & 2.11 & 1.85 & 2.41 & 2.22 & 2.32 & 2.48 & 2.77 & 2.77 & 2.93 & 2.93 \\
Insurance & 1.96 & 1.72 & 2.41 & 2.22 & 2.32 & 2.48 & 2.77 & 2.77 & 2.93 & 2.93 \\
Comunitary, personal and domestic services & 1.42 & 1.24 & 1.69 & 1.56 & 1.63 & 1.67 & 1.65 & 1.70 & 1.78 & 1.83 \\
Central and municipal governments & 1.05 & 0.92 & 1.33 & 1.22 & 1.31 & 1.52 & 1.53 & 1.54 & 1.61 & 1.63 \\
\hline
\end{tabular}

Source: MITRAB (Ministry of Labor)

Notes: *No negotiation. Same minimum wage as in previous year.

${ }^{* *}$ Agricultural workers receive food (in-kind) in addition to this pay (Artículo No. 202 Código del Trabajo) 
Table 2: Percent of Workers in Nicaragua Earning Within $20 \%$, Below and Above the Legal Minimum Wage, By Sector (averages over 1998-2006).

\begin{tabular}{lcccc}
\hline \hline Sector & $\begin{array}{c}\text { Below } \\
\text { MW }\end{array}$ & $\begin{array}{c}\text { At } \\
\text { MW }\end{array}$ & $\begin{array}{c}\text { Above } \\
\text { MW }\end{array}$ & $\begin{array}{c}\text { Sample } \\
\text { Size }\end{array}$ \\
\hline All Workers: & & & & \\
Private Covered Sector & 23.3 & 25.5 & 51.3 & 11614 \\
$\quad$ Large Firms & 11.4 & 24.2 & 64.5 & 5533 \\
$\quad$ Small Firms & 34.2 & 26.6 & 39.2 & 6055 \\
Covered Public Sector & 4.1 & 9.4 & 86.5 & 1939 \\
Uncovered Self-employed Sector & 24.6 & 15.6 & 59.9 & 8358 \\
\hline Full-time Workers Only & & & & \\
Private Covered Sector & 20.7 & 26.4 & 52.9 & 4803 \\
$\quad$ Large Firms & 10.0 & 23.7 & 66.3 & 2500 \\
$\quad$ Small Firms & 32.5 & 29.4 & 38.2 & 2283 \\
Covered Public Sector & 2.8 & 8.9 & 88.3 & 864 \\
Uncovered Self-employed Sector & 25.4 & 15.9 & 58.9 & 3067 \\
\hline
\end{tabular}

Source: Author's calculations using FIDEG and MITRAB data. 
Table 3: Elasticity of the Wage With Respect to the Minimum Wage in the Covered Sector

\begin{tabular}{|c|c|c|c|c|c|c|c|}
\hline \multirow{2}{*}{$\begin{array}{l}\text { For workers who remain in the } \\
\text { following sectors at time } t \text { and } t+1 \text { : }\end{array}$} & \multicolumn{2}{|c|}{ All Workers } & \multicolumn{2}{|c|}{$\begin{array}{c}\text { All Workers within } \\
20 \% \text { of } \\
\text { MW at time } t\end{array}$} & \multicolumn{3}{|c|}{$\begin{array}{l}\text { Full-time Workers } \\
\text { within } 20 \% \text { of } \\
\text { MW at time } t\end{array}$} \\
\hline & Coeff. & $\begin{array}{c}\text { Standard } \\
\text { Error }\end{array}$ & Coeff. & $\begin{array}{c}\text { Standard } \\
\text { Error }\end{array}$ & Coeff. & $\begin{array}{r}\text { Standa } \\
\text { Error }\end{array}$ & \\
\hline private covered & 0.247 & 0.237 & 0.579 & $0.267 * *$ & 0.651 & 0.084 & \\
\hline large-firm private & -0.222 & 0.345 & 0.561 & 0.414 & 1.037 & 0.365 & $* *$ \\
\hline small-firm private & 0.094 & 0.588 & 0.306 & $0.117 * *$ & 0.702 & 0.224 & $* *$ \\
\hline self-employed & 0.094 & 0.420 & 0.652 & 0.493 & -0.173 & 0.202 & \\
\hline
\end{tabular}

Notes: ${ }^{* \star *}=$ significant at $1 \%,{ }^{* *}=$ significant at $5 \%,{ }^{*}=$ significant at $10 \%$

The dependent variable is the change in the log of hourly wage and the key independent variable is the change in the real minimum wage;

we report the estimated coefficients for $\alpha_{1}$ in equation (1) for samples identified by row and column. Reported standard errors are robust to heteroskedasticity and corrected for clustering of errors in the industry of the worker (which also corresponds to the minimum wage category). 
Table 4: Marginal Impact of Minimum Wages on the Probability that a Worker Keeps His/Her Employment in the Covered Sector

\begin{tabular}{|c|c|c|c|c|c|c|}
\hline \multirow{2}{*}{$\begin{array}{l}\text { For workers in the } \\
\text { following sectors at time t: }\end{array}$} & \multicolumn{2}{|c|}{ All Workers } & \multicolumn{2}{|c|}{$\begin{array}{l}\text { All workers within } 20 \% \text { of } \\
\text { MW at time } t\end{array}$} & \multicolumn{2}{|c|}{$\begin{array}{c}\text { Full-time workers } \\
\text { within } 20 \% \text { of } \mathrm{MW} \text { at } \\
\text { time } \mathrm{t}\end{array}$} \\
\hline & $\begin{array}{c}\text { Marginal } \\
\text { Effect }\end{array}$ & Standard Error & $\begin{array}{c}\text { Marginal } \\
\text { Effect }\end{array}$ & $\begin{array}{c}\text { Standard } \\
\text { Error }\end{array}$ & $\begin{array}{c}\text { Marginal } \\
\text { Effect }\end{array}$ & $\begin{array}{c}\text { Standard } \\
\text { Error }\end{array}$ \\
\hline private covered & -0.310 & $0.099 * * *$ & -0.522 & $0.189^{* * *}$ & -0.509 & 0.382 \\
\hline large-firm private & -0.615 & $0.219 * * *$ & -1.197 & $0.266 \quad * * *$ & -2.126 & $0.724 * * *$ \\
\hline small-firm private & 0.038 & 0.393 & -0.089 & 0.428 & -0.847 & 1.358 \\
\hline
\end{tabular}

Notes: Table reports marginal effects evaluated at the means of all variables, from estimates of $\alpha_{1}$ in equation (2) using probit regressions for samples identified by row and column. A positive coefficient means that higher minimum wages increase the probability that a worker stays in the indicated covered sector. ${ }^{* * *}=$ significant at $1 \%,{ }^{* *}=$ significant at $5 \%,{ }^{*}=$ significant at $10 \%$. Reported standard errors are robust to heteroskedasticity and corrected for clustering of errors in the industry of the worker (which also corresponds to the minimum wage category). 
Table 5: Marginal Impact of Minimum Wages on the Probability of Leaving the Private Covered Sector for Another Sector

\begin{tabular}{|c|c|c|c|c|c|c|}
\hline \multirow[b]{2}{*}{ Destination Sector: } & \multicolumn{2}{|c|}{ All Workers } & \multicolumn{2}{|c|}{$\begin{array}{l}\text { All Workers within } \\
20 \% \text { of } \mathrm{MW} \text { at time } \mathrm{t}\end{array}$} & \multicolumn{2}{|c|}{$\begin{array}{c}\text { Full-time Workers } \\
\text { within } 20 \% \text { of MW at } \\
\text { time t }\end{array}$} \\
\hline & $\begin{array}{l}\text { Marginal } \\
\text { Effect }\end{array}$ & $\begin{array}{l}\text { Standard } \\
\text { Error }\end{array}$ & $\begin{array}{l}\text { Marginal } \\
\text { Effect }\end{array}$ & $\begin{array}{l}\text { Standard } \\
\text { Error }\end{array}$ & $\begin{array}{c}\text { Marginal } \\
\text { Effect }\end{array}$ & $\begin{array}{l}\text { Standard } \\
\text { Error }\end{array}$ \\
\hline \multicolumn{7}{|c|}{ Panel A: Multinomial Logit Regression (Origin is Private Covered Sector) } \\
\hline Public & 0.069 & $0.031 * *$ & 0.112 & $0.024^{* * *}$ & -0.302 & 0.418 \\
\hline Self-employed & -0.018 & 0.066 & 0.043 & 0.100 & 0.206 & 0.211 \\
\hline Unpaid Family Worker & 0.144 & $0.079 *$ & 0.174 & $0.063^{* * *}$ & 0.421 & $0.081 * * *$ \\
\hline Unemployed & -0.046 & 0.047 & -0.035 & 0.047 & 0.086 & 0.108 \\
\hline Not in the Labor Force & 0.152 & $0.063^{* *}$ & 0.213 & $0.056^{* * *}$ & -0.068 & 0.165 \\
\hline \multicolumn{7}{|c|}{ Panel B: Unconditional Probabilities of Leaving the Private Covered Sector } \\
\hline Stay in Private Sector & & 0.547 & & 0.540 & & 0.558 \\
\hline Public & & 0.036 & & 0.042 & & 0.036 \\
\hline Self-employed & & 0.107 & & 0.111 & & 0.103 \\
\hline Unpaid Family Worker & & 0.047 & & 0.053 & & 0.046 \\
\hline Unemployed & & 0.047 & & 0.042 & & 0.042 \\
\hline Not in the Labor Force & & 0.219 & & 0.211 & & 0.213 \\
\hline Sample Size & & 9247 & & 2593 & & 1016 \\
\hline
\end{tabular}

Notes: Panel A provides marginal effects, based on estimates of $\alpha_{1 \mathrm{kz}}$, evaluated at the means of all variables, in equation (3) using multinomial logit regressions, respectively, for samples identified by row and column. A positive coefficient means that higher minimum wages increase the probability of a transition from the private covered sector (and into the indicated uncovered sector). ${ }^{* * *}=$ significant at $1 \%,{ }^{* *}=$ significant at $5 \%,{ }^{*}=$ significant at $10 \%$. Reported standard errors are robust to heteroskedasticity and corrected for clustering of errors in the industry of the worker (which also corresponds to the minimum wage category). 
Table 6: Marginal Impact of Minimum Wages on the Probability of Entering the Private Covered Sector from Another Sector

\begin{tabular}{|c|c|c|c|c|c|c|}
\hline \multirow[b]{2}{*}{ Origin Sector: } & \multicolumn{2}{|c|}{ All Workers } & \multicolumn{2}{|c|}{$\begin{array}{l}\text { All Workers within } \\
20 \% \text { of } M W \text { at time } t\end{array}$} & \multicolumn{2}{|c|}{$\begin{array}{c}\text { Full-time Workers } \\
\text { within } 20 \% \text { of } M W \text { at } \\
\text { time } t\end{array}$} \\
\hline & $\begin{array}{l}\text { Marginal } \\
\text { Effect }\end{array}$ & $\begin{array}{l}\text { Standard } \\
\text { Error }\end{array}$ & $\begin{array}{c}\text { Marginal } \\
\text { Effect }\end{array}$ & $\begin{array}{l}\text { Standard } \\
\text { Error }\end{array}$ & $\begin{array}{l}\text { Marginal } \\
\text { Effect }\end{array}$ & $\begin{array}{l}\text { Standard } \\
\text { Error }\end{array}$ \\
\hline
\end{tabular}

Panel A: Probit Regression (Destination is the Private Covered Sector)

\begin{tabular}{|c|c|c|c|c|c|c|c|c|c|}
\hline All Others (non-private) & -0.095 & 0.125 & & -0.524 & 0.079 & $* * *$ & -2.696 & 6.229 & $* * * *$ \\
\hline Public & -7.925 & 1.499 & $* * *$ & -7.874 & 1.934 & $* * *$ & -20.421 & 5.133 & $* * *$ \\
\hline Self-employed & -0.157 & 0.081 & * & -0.281 & 0.042 & $* * *$ & -0.564 & 0.284 & $* *$ \\
\hline Unpaid Family Worker & 0.119 & 0.078 & & n.a. & n.a. & & n.a. & n.a. & \\
\hline
\end{tabular}

Panel B: Unconditional Probability of Entering the Private Sector from Another Sector

\begin{tabular}{l|c|c|c} 
All Others (non-private) & 0.109 & 0.131 & 0.207 \\
Public & 0.219 & 0.256 & 0.268 \\
Self-employed & 0.087 & 0.083 & 0.119 \\
Unpaid Family Worker & 0.097 & n.a. & n.a. \\
\hline Sample Size & 3581 & 1263 & 676 \\
\hline
\end{tabular}

Notes: Table provide marginal effects of the estimated $\alpha_{1 z}$ in a variant of equation (3) using probit for samples identified by row and column. A positive coefficient means that higher minimum wages increase the probability of a transition into the private covered sector from another sector. ${ }^{* * *}=$ significant at $1 \%,{ }^{* *}=$ significant at $5 \%,{ }^{*}=$ significant at $10 \%$. Reported standard errors are robust to heteroskedasticity and corrected for clustering of errors in the industry of the worker (which also corresponds to the minimum wage category). 
Table 7: Percent of Workers Earning Within 20\%, Below and Above the Legal Minimum Wage, by Whether the Household is Poor or Not

\begin{tabular}{l|ccc|ccc|cccc}
\hline \hline & \multicolumn{3}{|c|}{ All Workers } & \multicolumn{3}{c|}{ Heads of Household } & \multicolumn{3}{c}{ Non-Heads of Household } \\
Poverty & Below & At & Above & Below & At & Above & Below & & Above \\
Status & MW & MW & MW & MW & MW & MW & MW & At & MW & MW \\
\cline { 2 - 12 } Extremely Poor & 51 & 29 & 16 & 45 & 21 & 9 & 54 & 34 & 21 \\
Poor & 27 & 27 & 17 & 26 & 21 & 10 & 28 & 30 & 21 \\
Not Poor & 22 & 44 & 67 & 59 & 57 & 81 & 18 & 36 & 58 \\
\hline Sample Size & 4837 & 4444 & 12648 & 1302 & 1324 & 5314 & 3535 & 3120 & 7334 \\
\hline
\end{tabular}

Note: Using the FIDEG definition of poverty. 
Table 8: Impact of Changes in Minimum Wages on the Probability that a Household is Poor in $t+1$

\begin{tabular}{lcc}
\hline \hline & $\begin{array}{c}\text { Marginal } \\
\text { Effect }\end{array}$ & $\begin{array}{c}\text { Standard } \\
\text { Error }\end{array}$ \\
\hline All & -0.070 & 0.100 \\
Head of HH & -0.124 & $0.065 \quad *$ \\
Non-Head of HH & -0.033 & 0.108 \\
Male Head of HH & -0.120 & 0.116 \\
Female Head of HH & -0.101 & 0.076 \\
Head of HH with 1 worker & -0.009 & $0.064 \quad *$ ** \\
Head of HH with 2+ workers & -0.166 & $0.069 \quad$ \\
\hline
\end{tabular}

Note: Using the survey's definition of poverty. A negative coefficient means that higher minimum wages lower the probability that a household is poor at time $\mathrm{t}+1 .{ }^{* * *}=$ significant at $1 \%,{ }^{*}=$ significant at $5 \%,{ }^{*}=$ significant at $10 \%$. Reported standard errors are robust to heteroskedasticity and corrected for clustering of errors in the industry of the worker (which also corresponds to the minimum wage category). 
Table 9: Marginal Impact of Minimum Wages on the Probability of a Worker's Family Transitions Into or Out of Poverty

\begin{tabular}{|c|c|c|c|c|c|}
\hline & \multicolumn{3}{|c|}{$\begin{array}{l}\text { Transition from } \\
\text { Poor to Non-Poor }\end{array}$} & \multicolumn{2}{|c|}{$\begin{array}{l}\text { Transition from } \\
\text { Non-Poor to Poor }\end{array}$} \\
\hline & $\begin{array}{c}\text { Marginal } \\
\text { Effect }\end{array}$ & $\begin{array}{r}\text { Standa } \\
\text { Error }\end{array}$ & & $\begin{array}{c}\text { Marginal } \\
\text { Effect }\end{array}$ & $\begin{array}{c}\text { Standard } \\
\text { Error }\end{array}$ \\
\hline All Workers & 0.122 & 0.066 & * & 0.113 & 0.078 \\
\hline Head of Household & 0.160 & 0.096 & * & 0.075 & 0.141 \\
\hline Non-Head of Household & 0.095 & 0.104 & & 0.143 & 0.154 \\
\hline Male Head of $\mathrm{HH}$ & 0.145 & 0.083 & * & 0.056 & 0.123 \\
\hline Female Head of $\mathrm{HH}$ & 0.183 & 0.079 & $* *$ & 0.160 & 0.155 \\
\hline Head of HH with 1 worker & 0.132 & 0.101 & & 0.271 & 0.262 \\
\hline Head of $\mathrm{HH}$ with $2+$ workers & 0.172 & 0.102 & * & 0.013 & 0.105 \\
\hline
\end{tabular}

Note: A positive coefficient means that higher minimum wages increase the probability of a transition. ${ }^{* * *}=$ significant at $1 \%,{ }^{* *}=$ significant at $5 \%,{ }^{*}=$ significant at $10 \%$. Reported standard errors are robust to heteroskedasticity and corrected for clustering of errors in the industry of the worker (which also corresponds to the minimum wage category). 
Table 10: Marginal Impact of Minimum Wages on the Probability that a Worker Keeps His/Her Job in the Covered Sector

\begin{tabular}{|c|c|c|c|c|c|}
\hline \multirow{2}{*}{$\begin{array}{l}\text { For workers in the following } \\
\text { sectors at time t: }\end{array}$} & \multicolumn{2}{|c|}{$\begin{array}{c}\text { All Heads of } \\
\text { Households }(\mathrm{HH})\end{array}$} & \multicolumn{3}{|c|}{ All Non-heads of $\mathrm{HH}$} \\
\hline & $\begin{array}{c}\text { Marginal } \\
\text { Effect }\end{array}$ & $\begin{array}{l}\text { Standard } \\
\text { Error }\end{array}$ & $\begin{array}{c}\text { Marginal } \\
\text { Effect }\end{array}$ & $\begin{array}{r}\text { Standar } \\
\text { Error }\end{array}$ & \\
\hline private & -0.175 & 0.110 & -0.384 & 0.111 & *** \\
\hline large-firm private & -0.366 & $0.187 *$ & -0.753 & 0.230 & *** \\
\hline small-firm private & 0.005 & 0.399 & 0.057 & 0.386 & \\
\hline \multirow{2}{*}{$\begin{array}{l}\text { For workers in the following } \\
\text { sectors at time t: }\end{array}$} & \multicolumn{2}{|c|}{$\begin{array}{l}\text { All Heads of } \mathrm{HH} \text { within } \\
20 \% \text { of MW at time } \mathrm{t}\end{array}$} & \multicolumn{3}{|c|}{$\begin{array}{l}\text { All Non-Heads within } \\
20 \% \text { of MW at time t }\end{array}$} \\
\hline & $\begin{array}{l}\text { Marginal } \\
\text { Effect }\end{array}$ & $\begin{array}{l}\text { Standard } \\
\text { Error }\end{array}$ & $\begin{array}{c}\text { Marginal } \\
\text { Effect }\end{array}$ & $\begin{array}{c}\text { Standar } \\
\text { Error }\end{array}$ & \\
\hline private & -0.447 & $0.143^{* * *}$ & -0.558 & 0.213 & ** \\
\hline large-firm private & -0.884 & $0.084^{* * *}$ & -1.331 & 0.352 & *** \\
\hline small-firm private & -0.079 & 0.459 & -0.094 & 0.413 & \\
\hline
\end{tabular}

Notes: Table reports marginal effects evaluated at the means of all variables, from estimates of $\alpha_{1}$ in equation (2) using probit regressions for samples identified by row and column. A positive coefficient means that higher minimum wages increase the probability that a worker stays in the indicated covered sector. ${ }^{* * *}=$ significant at $1 \%$, ${ }^{* *}=$ significant at $5 \%,{ }^{*}=$ significant at $10 \%$. Reported standard errors are robust to heteroskedasticity and corrected for clustering of errors in the industry of the worker (which also corresponds to the minimum wage category). 
Table 11: Marginal Effect of Minimum Wages on the Probability of Leaving the Private Covered Sector for Another Sector

\begin{tabular}{|c|c|c|c|c|c|c|}
\hline \multirow{2}{*}{$\begin{array}{l}\text { Origin: Private } \\
\text { Covered Sector } \\
\\
\text { Destination: }\end{array}$} & \multicolumn{3}{|c|}{$\begin{array}{c}\text { All Heads of } \\
\text { Households (HH) }\end{array}$} & \multicolumn{3}{|c|}{ All Non-heads of $\mathrm{HH}$} \\
\hline & $\begin{array}{c}\text { Marginal } \\
\text { Effect }\end{array}$ & $\begin{array}{l}\text { Standarc } \\
\text { Error }\end{array}$ & & $\begin{array}{c}\text { Marginal } \\
\text { Effect }\end{array}$ & $\begin{array}{r}\text { Standa } \\
\text { Error }\end{array}$ & \\
\hline Public & 0.097 & 0.031 & *** & 0.074 & 0.059 & \\
\hline Self-employed & 0.244 & 0.103 & ** & -0.264 & 0.075 & $* * *$ \\
\hline Unpaid Family Worker & -0.175 & 0.067 & ** & 0.192 & 0.095 & $* *$ \\
\hline Unemployed & -0.097 & 0.060 & & -0.009 & 0.041 & \\
\hline Not in the Labor Force & -0.199 & 0.109 & * & 0.262 & 0.052 & $* \star *$ \\
\hline
\end{tabular}

\begin{tabular}{|c|c|c|c|c|c|c|}
\hline \multirow{2}{*}{$\begin{array}{l}\text { Origin: Private } \\
\text { Covered Sector } \\
\text { Destination: }\end{array}$} & \multicolumn{3}{|c|}{$\begin{array}{l}\text { All Heads of } \mathrm{HH} \text { within } \\
20 \% \text { of MW at time } \mathrm{t}\end{array}$} & \multicolumn{3}{|c|}{$\begin{array}{l}\text { All Non-Heads within } \\
20 \% \text { of MW at time t }\end{array}$} \\
\hline & $\begin{array}{c}\text { Marginal } \\
\text { Effect }\end{array}$ & $\begin{array}{c}\text { Standarc } \\
\text { Error }\end{array}$ & & $\begin{array}{c}\text { Marginal } \\
\text { Effect }\end{array}$ & $\begin{array}{r}\text { Standa } \\
\text { Error } \\
\end{array}$ & \\
\hline Public & 0.143 & 0.313 & & 0.110 & 0.062 & * \\
\hline Self-employed & 0.287 & 0.159 & * & -0.146 & 0.052 & ** \\
\hline Unpaid Family Worker & -0.084 & 0.055 & & 0.264 & 0.128 & ** \\
\hline Unemployed & -0.070 & 0.029 & ** & -0.010 & 0.052 & \\
\hline Not in the Labor Force & -0.072 & 0.140 & & 0.289 & 0.063 & *** \\
\hline
\end{tabular}

Notes: Table provides marginal effects, based on estimates of $\alpha_{1 \mathrm{kz}}$, evaluated at the means of all variables, in equation (3) using multinomial logit regressions, respectively, for samples identified by row and column. A positive coefficient means that higher minimum wages increase the probability of a transition from the private covered sector. ${ }^{* * *}=$ significant at $1 \%,{ }^{* *}=$ significant at $5 \%,{ }^{*}=$ significant at $10 \%$. Reported standard errors are robust to heteroskedasticity and corrected for clustering of errors in the industry of the worker (which also indicates the minimum wage category). 
Table A1: Descriptive Statistics of Panel Data

\begin{tabular}{|c|c|c|c|}
\hline \multicolumn{2}{|c|}{$\begin{array}{l}\text { Individual Data (for the sample used to estimate the } \\
\text { employment equations): }\end{array}$} & \multicolumn{2}{|l|}{$\begin{array}{l}\text { Household Data (for the sample used to } \\
\text { estimate the employment equations): }\end{array}$} \\
\hline Number of Individuals & 8682 & \multirow{6}{*}{$\begin{array}{l}\text { Number of households } \\
\text { Number of observations } \\
\text { Average number of observations per household } \\
\text { Share of households headed by women } \\
\text { Distribution of households by number of } \\
\text { members }\end{array}$} & \multirow{3}{*}{$\begin{array}{c}3378 \\
14334 \\
4.2\end{array}$} \\
\hline Number of observations & 27000 & & \\
\hline $\begin{array}{l}\text { Average number of observations per } \\
\text { individual }\end{array}$ & 3.1 & & \\
\hline Percent of individuals with 9 observations & 6.86 & & 34.28 \\
\hline Percent of individuals with 8 observations & 5.51 & & \\
\hline Percent of individuals with 7 observations & 5.83 & & \\
\hline Percent of individuals with 6 observations & 6.63 & 1 & 1.22 \\
\hline Percent of individuals with 5 observations & 9.54 & 2 & 3.64 \\
\hline Percent of individuals with 4 observations & 13.41 & 3 & 8.02 \\
\hline Percent of individuals with 3 observations & 19.95 & 4 & 13.52 \\
\hline Percent of individuals with 2 observations & 32.27 & $\begin{array}{l}5 \\
6\end{array}$ & $\begin{array}{l}15.36 \\
14.33\end{array}$ \\
\hline Percent Female & 42.07 & more than 6 & 43.91 \\
\hline Percent Urban & 47.21 & & \\
\hline Distribution by Education Level & & \multicolumn{2}{|l|}{$\begin{array}{l}\text { Distribution of households by number of working } \\
\text { members }\end{array}$} \\
\hline None (0 years of education) & 10.37 & 1 & 27.51 \\
\hline Primary (1-8 years of education) & 45.17 & 2 & 31.89 \\
\hline Secondary (9-12 years of education) & 35.15 & 3 & 19.06 \\
\hline Higher & 9.31 & $\begin{array}{l}4 \\
5\end{array}$ & $\begin{array}{c}11.48 \\
5.52\end{array}$ \\
\hline Percent working in: & $\underline{\text { All Workers }}$ & 6 & 3.43 \\
\hline large private sector covered firms & 13.26 & more than 6 & 0.83 \\
\hline small private sector covered firms & 14.69 & & \\
\hline $\begin{array}{l}\text { public sector } \\
\text { self-employed }\end{array}$ & $\begin{array}{c}4.71 \\
28.91\end{array}$ & \multicolumn{2}{|l|}{$\begin{array}{l}\text { Distribution of households by number of } \\
\text { nonworking members }\end{array}$} \\
\hline unpaid family workers & 19.40 & 1 & 10.06 \\
\hline unemployed & 2.13 & 2 & 15.77 \\
\hline out of the labor force & 16.91 & 3 & 18.28 \\
\hline full-time & 64.00 & 4 & 16.64 \\
\hline part-time & 36.00 & 5 & 13.50 \\
\hline \multicolumn{2}{|c|}{ Within $20 \%$ of minimum wage at time $t$} & 6 & 10.55 \\
\hline $\begin{array}{l}\text { Percent working in: } \\
\text { large private sector covered firms } \\
\text { small private sector covered firms } \\
\text { public sector } \\
\text { full-time } \\
\text { part-time }\end{array}$ & $\begin{array}{l}27.58 \\
14.08 \\
34.39 \\
71.54 \\
28.46\end{array}$ & more than 6 & 14.71 \\
\hline
\end{tabular}


Table A2: Comparison of the FIDEG data with LSMS data -- Distribution of Employed

\begin{tabular}{|c|c|c|c|c|}
\hline & FID & EG & & $\begin{array}{l}\text { NV - } \\
\text { MS }\end{array}$ \\
\hline & 1998 & 2005 & 1998 & 2005 \\
\hline Economic Sector & & & & \\
\hline Primary & 33.9 & 27.2 & 35.9 & 35.1 \\
\hline Agriculture & 33.9 & 27.2 & 35.9 & 35.1 \\
\hline Secondary & 15.2 & 17.8 & 14.6 & 18.7 \\
\hline Mines & - & 0.1 & 0.5 & 0.4 \\
\hline Manufacturing & 15.2 & 15.3 & 9.4 & 14.0 \\
\hline Special regime & - & 2.3 & - & - \\
\hline Construction & - & - & 4.7 & 4.2 \\
\hline Tertiary & 50.9 & 55.0 & 49.4 & 46.2 \\
\hline Electricity, gas and water & - & - & 0.6 & 0.8 \\
\hline Commerce, hotels and restaurants & 50.4 & 48.0 & 24.1 & 21.7 \\
\hline Transportation and communication & - & 3.1 & 3.7 & 3.4 \\
\hline Finance & - & - & 0.4 & 0.7 \\
\hline Personal and social services & 0.5 & 3.9 & 20.6 & 19.9 \\
\hline Employment Status: & & & & \\
\hline Owner & 3.5 & 3.2 & 3.6 & 4.5 \\
\hline Self-employed & 32.5 & 32.6 & 27.5 & 30.2 \\
\hline Paid employee & 43.9 & 40.5 & 52.8 & 49.0 \\
\hline Unpaid & 20.1 & 23.7 & 15.8 & 16.3 \\
\hline Unemployment & & & & \\
\hline National & 7.7 & 4.2 & 11.6 & 4.0 \\
\hline Urban & 9.5 & 5.1 & 13.9 & 5.8 \\
\hline Rural & 5.9 & 3.4 & 8.7 & 1.5 \\
\hline Men & 4.6 & 2.9 & 10.6 & 3.7 \\
\hline Women & 12.2 & 5.8 & 13.5 & 4.5 \\
\hline Mean Monthly Salary (1994 Cord & & & & \\
\hline National & 671.5 & 759.9 & 804.1 & 864.7 \\
\hline Urban & 724.8 & 812.3 & 995.3 & 1041.3 \\
\hline Rural & 601.5 & 689.3 & 502.8 & 570.0 \\
\hline Men & 775.7 & 933.2 & 896.0 & 948.3 \\
\hline Women & 534.8 & 569.8 & 637.3 & 714.9 \\
\hline Median Monthly Salary (1994 Co & & & & \\
\hline National & 385.6 & 465.4 & 449.9 & 500.4 \\
\hline Urban & 501.3 & 558.6 & 525.1 & 620.6 \\
\hline Rural & 334.2 & 403.3 & 321.3 & 349.1 \\
\hline Men & 501.3 & 581.8 & 462.7 & 543.1 \\
\hline Women & 335.1 & 387.9 & 385.6 & 465.5 \\
\hline
\end{tabular}


Table A3: Marginal Impact of Minimum Wages on the Probability of Leaving the Large Firm Private Covered Sector for Another Sector

\begin{tabular}{lccc}
\hline \multicolumn{4}{c}{ Origin Sector: Large-firm Private Sector } \\
Marginal \\
Eestination Sector: & 0.478 & $0.116^{* * *}$ \\
\hline Public & 0.837 & $0.399^{* *}$ \\
Small-firm & 0.580 & $0.045^{* * *}$ \\
Self-employed & 0.806 & $0.225^{* * *}$ \\
Unpaid Family Worker & 0.206 & 0.248 & \\
Unemployed & 0.738 & $0.279 \quad * *$ \\
Not in the Labor Force & &
\end{tabular}

Notes: Marginal effects are calculated based on estimates of $\alpha_{1 \mathrm{kz}}$, evaluated at the means of all variables, in equation (3) using multinomial logit regressions, respectively, for samples identified by row and column. A positive coefficient means that higher minimum wages increase the probability of a transition from the large firm private covered sector. ${ }^{* * *}=$ significant at $1 \%,{ }^{* *}=$ significant at $5 \%,{ }^{*}=$ significant at $10 \%$. Reported standard errors are robust to heteroskedasticity and corrected for clustering of errors in the industry of the worker (which also corresponds to the minimum wage category). 
Table A4: Marginal Impact of Minimum Wages on the Probability of Entering the Large Firm Private Covered Sector from Another Sector

Destination Sector: Large-firm Private Sector

\begin{tabular}{|c|c|c|}
\hline Origin Sector: & Coefficient & Standard Error \\
\hline Public & -0.057 & 0.043 \\
\hline Small-firm & 0.064 & 0.211 \\
\hline Self-employed & -0.027 & 0.045 \\
\hline Unpaid Family Worker & 0.085 & 0.022 \\
\hline
\end{tabular}

Notes: Table provide marginal effects of the estimated $\alpha_{1 z}$ in a variant of equation (3) using probit estimation for samples identified by row and column. A positive coefficient means that higher minimum wages increase the probability of a transition into the large firm private covered sector from another sector. ${ }^{* * *}=$ significant at $1 \%,{ }^{* *}=$ significant at $5 \%$, ${ }^{*}=$ significant at $10 \%$. Reported standard errors are robust to heteroskedasticity and corrected for clustering of errors in the industry of the worker (which also corresponds to the minimum wage category). 
Table A5: Poverty Lines and Minimum Wages in Nominal Córdobas

Panel A: Relationship between the FIDEG and INEC Poverty Lines

\begin{tabular}{|c|c|c|c|c|c|c|c|c|c|c|}
\hline \multirow[b]{2}{*}{ Year } & \multicolumn{2}{|c|}{ FIDEG } & \multicolumn{2}{|c|}{ INEC } & \multicolumn{2}{|c|}{ FIDEG } & \multicolumn{2}{|c|}{ INEC } & \multicolumn{2}{|c|}{ FIDEG/INEC } \\
\hline & $\begin{array}{c}\text { Extreme } \\
\text { Poverty } \\
\text { monthly } \\
\text { for } 6 \\
\text { individ. }\end{array}$ & $\begin{array}{c}\text { Poverty } \\
\text { monthly } \\
\text { for } 6 \\
\text { individ. }\end{array}$ & $\begin{array}{c}\text { Extreme } \\
\text { Poverty } \\
\text { annual } \\
\text { for } 1 \\
\text { individ. }\end{array}$ & $\begin{array}{c}\text { Poverty } \\
\text { annual } \\
\text { for } 1 \\
\text { individ. }\end{array}$ & $\begin{array}{c}\text { Extreme } \\
\text { Poverty } \\
\text { monthly } \\
\text { for } 1 \\
\text { individ. }\end{array}$ & $\begin{array}{l}\text { Poverty } \\
\text { monthly } \\
\text { for } 1 \\
\text { individ. }\end{array}$ & $\begin{array}{c}\text { Extreme } \\
\text { Poverty } \\
\text { monthly } \\
\text { for } 1 \\
\text { individ. }\end{array}$ & $\begin{array}{c}\text { Poverty } \\
\text { monthly } \\
\text { for } 1 \\
\text { individ. }\end{array}$ & $\begin{array}{c}\text { Extreme } \\
\text { Poverty }\end{array}$ & Poverty \\
\hline 1998 & 1578.2 & 3156.5 & 2246.0 & 4259.0 & 263.0 & 526.1 & 187.2 & 354.9 & 1.4 & 1.5 \\
\hline 1999 & 1694.1 & 3388.2 & & & 282.3 & 564.7 & & & & \\
\hline 2000 & 1852.4 & 3704.7 & & & 308.7 & 617.5 & & & & \\
\hline 2001 & 1980.1 & 3960.3 & 2691.0 & 5157.0 & 330.0 & 660.0 & 224.3 & 429.8 & 1.5 & 1.5 \\
\hline 2002 & 2078.1 & 4156.2 & & & 346.3 & 692.7 & & & & \\
\hline 2003 & 2208.9 & 4417.9 & & & 368.2 & 736.3 & & & & \\
\hline 2004 & 2464.6 & 4929.2 & & & 410.8 & 821.5 & & & & \\
\hline 2005 & 2682.7 & 5365.3 & 3927.5 & 7154.8 & 447.1 & 894.2 & 327.3 & 596.2 & 1.4 & 1.5 \\
\hline 2006 & 2937.7 & 5875.4 & & & 489.6 & 979.2 & & & & \\
\hline
\end{tabular}

Panel B: Relationship Between the Minimum Wage and the FIDEG Poverty Lines

\begin{tabular}{|c|c|c|c|c|c|c|c|c|c|c|}
\hline Year & $\begin{array}{l}\text { Nominal } \\
\text { Minimum } \\
\text { Monthly } \\
\text { Min } \\
\text { Wage }\end{array}$ & $\begin{array}{l}\text { MW as } \\
\% \text { of } \\
\text { Extreme } \\
\text { Poverty } \\
\text { for } 1 \\
\text { individual }\end{array}$ & $\begin{array}{l}\text { MW as } \\
\% \text { of } \\
\text { Poverty } \\
\text { for } 1 \\
\text { individual }\end{array}$ & $\begin{array}{l}\text { MW as } \\
\% \text { of } \\
\text { Extreme } \\
\text { Poverty } \\
\text { for HH } \\
\text { of } 6 \\
\text { individ. }\end{array}$ & $\begin{array}{l}\text { MW as } \\
\% \text { of } \\
\text { Poverty } \\
\text { for HH of } \\
6 \text { individ. }\end{array}$ & $\begin{array}{c}\text { Nominal } \\
\text { Average } \\
\text { Monthly } \\
\text { Min } \\
\text { Wage }\end{array}$ & $\begin{array}{l}\text { MW as } \\
\% \text { of } \\
\text { Extreme } \\
\frac{\text { Poverty }}{\text { for } 1} \\
\text { individual }\end{array}$ & $\begin{array}{l}\text { MW as } \% \\
\text { of Poverty } \\
\text { for } 1 \\
\text { individual }\end{array}$ & $\begin{array}{l}\text { MW as \% of } \\
\begin{array}{c}\text { Extreme } \\
\text { Poverty for } \\
\text { HH of } 6 \\
\text { individ. }\end{array}\end{array}$ & $\begin{array}{l}\text { MW as } \\
\% \text { of } \\
\text { Poverty } \\
\text { for } \mathrm{HH} \\
\text { of } 6 \\
\text { individ. }\end{array}$ \\
\hline 1998 & 300.0 & 114.1 & 57.0 & 19.0 & 9.5 & 401.8 & 152.8 & 76.4 & 25.5 & 12.7 \\
\hline 1999 & 450.0 & 159.4 & 79.7 & 26.6 & 13.3 & 610.6 & 216.3 & 108.1 & 36.0 & 18.0 \\
\hline 2000 & 450.0 & 145.8 & 72.9 & 24.3 & 12.1 & 632.9 & 205.0 & 102.5 & 34.2 & 17.1 \\
\hline 2001 & 550.0 & 166.7 & 83.3 & 27.8 & 13.9 & 724.1 & 219.4 & 109.7 & 36.6 & 18.3 \\
\hline 2002 & 580.0 & 167.5 & 83.7 & 27.9 & 14.0 & 783.1 & 226.1 & 113.1 & 37.7 & 18.8 \\
\hline 2003 & 615.0 & 167.0 & 83.5 & 27.8 & 13.9 & 859.5 & 233.5 & 116.7 & 38.9 & 19.5 \\
\hline 2004 & 669.0 & 162.9 & 81.4 & 27.1 & 13.6 & 914.0 & 222.5 & 111.3 & 37.1 & 18.5 \\
\hline 2005 & 769.0 & 172.0 & 86.0 & 28.7 & 14.3 & 1052.4 & 235.4 & 117.7 & 39.2 & 19.6 \\
\hline 2006 & 869.0 & 177.5 & 88.7 & 29.6 & 14.8 & 1242.3 & 253.7 & 126.9 & 42.3 & 21.1 \\
\hline
\end{tabular}

Sources: FIDEG, INEC and MITRAB 